\title{
A Biblioteca Virtual de Saúde Reprodutiva: dando voz ao usuário
}

\section{Maria do Carmo Avamilano Alvarez}

Dissertação apresentada ao Programa de Pós-Graduação em Saúde da Faculdade de Saúde Pública da Universidade de São Paulo para obtenção do título de Mestre em Saúde Pública.

Área de concentração: Saúde Materno-Infantil

Orientadora: Profa. Dra. Néia Schor 


\section{Universidade de São Paulo Faculdade de Saúde Pública}

\section{A Biblioteca Virtual de Saúde Reprodutiva: dando voz ao usuário}

Maria do Carmo Avamilano Alvarez

Dissertação apresentada ao Programa de Pós-Graduação em Saúde Pública da para obtenção do título de Mestre em Saúde Pública.

Área de Concentração: Saúde Materno-Infantil

Orientador: Profa. Dra. Néia Schor

São Paulo

2005 
Autorizo, exclusivamente para fins acadêmicos e científicos, a reprodução total ou parcial desta tese, por processos fotocopiadores.

Assinatura:

Data: 


\section{AGRADECIMENTOS}

À minha orientadora Néia Schor pela confiança e apoio.

Ao Departamento de Saúde Materno Infantil pela calorosa acolhida.

À Divisão de Engenharia Civil do Instituto de Pesquisas Tecnológicas (IPT), representada por Marlene Prado Merichelli e Ely Bernardi, por cederem o instrumento usado na pesquisa, a sala de bate-papo, numa fase bastante significativa.

À equipe da Seção de Informática da Faculdade de Saúde Pública pelo empenho e colaboração no uso do Fórum.

Às bibliotecárias e professoras doutoras Angela Maria Belloni Cuenca, Daisy Pires Noronha e Maria Teresinha Dias de Andrade por serem meus modelos e terem me encaminhado para a carreira acadêmica.

Aos companheiros da equipe Hálida Cristina Delbúcio, Prof. Dr. Ivan França Junior e Eidi Raquel F. Abdalla, que me fizeram acreditar na Biblioteca Virtual de Saúde Reprodutiva, em especial à Maria Lúcia E. de Faria Ferraz, que acompanhou todo o processo com dedicação e carinho.

Às colegas Cibele Araujo Camargo Marques Santos e Helene Mariko Ueno pelas colaborações técnicas.

Aos participantes dos grupos focais pela disponibilidade de tempo e atenção, numa época em que tempo é o bem mais valioso.

À minha família pelo amor, no sentido mais complexo e completo que esta palavra pode expressar.

Aos funcionários da biblioteca pela compreensão, ajuda e torcida. 
Alvarez M do C A . A Biblioteca Virtual de Saúde Reprodutiva: dando voz ao usuário. São Paulo; 2005. [Dissertação de Mestrado - Faculdade de Saúde Pública da USP]

\section{RESUMO}

A fundamentação teórica deste estudo baseia-se em pensadores que analisam as culturas modernas e pós-modernas, enfocando as tecnologias da informação e comunicação. Essas tecnologias têm adquirido destaque nos campos da pesquisa acadêmica e da ciência da informação. Com a intenção de aproximar os usuários pesquisadores dos estoques de informação institucionalizada estão sendo criadas as bibliotecas virtuais. A Biblioteca Virtual de Saúde Reprodutiva (BVSR), mantida pela Biblioteca e pelo Departamento de Saúde Materno-Infantil da Faculdade de Saúde Pública da USP, faz parte destas novas tecnologias e encontra-se no centro deste estudo. O objetivo deste trabalho é verificar como está se processando a comunicação entre a BVSR e o seu usuário, pesquisadores da área da saúde reprodutiva, procurando identificar as suas expectativas, se há barreiras nesta comunicação e melhorar as formas de promover uma comunicação interativa para ampliar o significado deste tipo de serviço. O método adotado é de natureza qualitativa e conhecido como grupo focal, que foi aplicado através de três reuniões em salas de chat (Internet relay chat) na Internet. Os resultados apontaram para a pouca divulgação da BVSR e a baixa assimilação da comunicação interativa pela sociedade. Várias sugestões para a melhoria da comunicação da BVSR foram colocadas, como: a criação de um espaço de encontro, integração das bases e outras BVs, disponibilização de fontes validadas, visual mais moderno, com a segmentação de acordo com os perfis de usuários, entre outras.

Palavras-chave: Bibliotecas virtuais. Tecnologia de comunicação. Internet. Comunicação interativa. Saúde reprodutiva. 
Alvarez M do CA. A Biblioteca Virtual em Saúde Reprodutiva: dando voz ao usuário. [The Reproductive Health Virtual Library: listening to the user]. São Paulo (BR); 2005. [M. Sc. Dissertation - Faculdade de Saúde Pública da Universidade de São Paulo, Brazil].

\section{SUMMARY}

The theoretical foundation of this study is based on theorists who analyze modern and post-modern cultures, focusing attention on information and communication technologies. These technologies have been achieved importance in academic research and information science fields. The virtual libraries have been created in order to allow the users to get closer to the institutionalized information stock. The Reproductive Health Virtual Library (RHVL), supported by the Library and the Department of Maternal and Child Health of Faculdade de Saúde Pública - USP, is part of these new technologies and is the subject of this study. The objective is to verify the communication process between the RHVL and its user, reproductive health researchers, attempting to identify his or her expectations, to perceive gaps in communication and to improve interactive communication to enhance the meaning of this kind of service. We adopted a qualitative method, known as focal group, which was applied to three meetings at chat rooms (Internet relay chat), on the internet. The results indicated the lack of awareness of RHVL and a poor acquisition of interactive communication by the society. Several suggestions were made, such as: meeting rooms, links among databases and other VLs, availability of validated sources, modern presentation, divisions according to the user profile, among others.

Keywords: Virtual Libraries. Communication Technology. Internet. Interactive Communication. Reproductive Health. 


\section{Índice}

1 TECNOLOGIAS DA INFORMAÇÃO E A COMUNICAÇÃO NO MUNDO CONTEMPORÂNEO

1.1 Algumas Reflexões a Partir de Pierre Lévy 4

1.2 As Opiniões de Outros Teóricos 11

1.3 A Exclusão Digital 18

2 INTERNET E PESQUISA ACADÊMICA 22

2.1 As Bibliotecas Virtuais 24

2.2 A Comunicação na Área das Bibliotecas Virtuais 29

3 A BIBLIOTECA VIRTUAL DE SAÚDE REPRODUTIVA 32

3.1 Conceito de Saúde Reprodutiva 32

3.2 Sobre a Proposta da Biblioteca Virtual de Saúde Reprodutiva (BVSR) e sua Implementação 35

3.3 Sobre as Categorias de Usuários 38

4 OBJETIVOS 40

5 PROCEDIMENTOS METODOLÓGICOS 41

5.1 Natureza da Pesquisa 41

5.2 Grupo Focal 43

5.3 Os Sujeitos da Pesquisa 47

5.4 Coleta de Dados 48

5.5 Tratamento e Análise dos Dados 52

5.6 Termo de Consentimento Livre e Esclarecido 53

6 RESULTADOS E DISCUSSÃO 53

6.1 Sobre o Grupo Focal via Internet 54

6.2 Respostas às Questões Focais 58

6.3 Discussões Paralelas nas Reuniões 76 
8 REFERÊNCIAS 90 ANEXOS

Anexo 1 - Site do PROSSIGA A1

Anexo 2 - Página das Bibliotecas Virtuais Temáticas A2

Anexo 3 - Site da Biblioteca Virtual de Saúde Reprodutiva A3

Anexo 4 - Instituições Contatadas da área de Saúde Reprodutiva $\quad$ A4 


\section{TECNOLOGIAS DA INFORMAÇÃO E A COMUNICAÇÃO NO MUNDO CONTEMPORÂNEO}

A tecnologia da informação e comunicação de maior destaque é a internet, considerada um poderoso instrumento no mundo contemporâneo. Vários teóricos têm refletido sobre este instrumento, alguns defendendo outros criticando as novas tecnologias.

A internet teve início nos anos 70 como um sistema militar, passando a ter força civil, social e global no processo de comunicação e informação principalmente nas últimas duas décadas. Originou-se da junção de duas tecnologias distintas, porém de mesma base eletrônica - a informática e as telecomunicações (SILVA 2001).

Atualmente o Brasil ocupa a oitava posição entre os países do mundo por número de hosts ${ }^{*}$ e os dados apontam para um crescimento elevado. Milhões de pessoas têm acesso a grandes quantidades de informação e a sociedade depende cada vez mais de sistemas automatizados para controle, armazenamento, distribuição e acesso a dados, gerados por milhares de processos inerentes às atividades de praticamente todos os ramos do conhecimento (CUENCA 2004).

Para uma análise da comunicação no mundo contemporâneo, o uso deste instrumento deve ser estudado, procurando-se levantar os pontos positivos e negativos que o permeiam.

Um dos aspectos criticados na internet é o excesso de informação disponibilizada, fato que tem confundido os pesquisadores, causando a impressão de que se está perdendo algum dado importante a cada momento e a dúvida quanto à qualidade das informações. Aliado a isso, as informações na internet são despadronizadas e desorganizadas, sem garantia de continuidade e privacidade (CIANCONI 2001).

* Comitê Gestor da Internet no Brasil. Disponível em http://www.cg.org.br. [2004 ago 30] 
Para tentar solucionar esses problemas algumas tentativas de organizar a informação disponibilizada na internet vêm sendo implementadas, com a finalidade de validá-la, tornando seu acesso mais ágil. Uma das iniciativas é o surgimento das bibliotecas virtuais, que procuram recolher, tratar e disponibilizar informações especializadas contidas nos sites ${ }^{*}$.

Um exemplo brasileiro são as bibliotecas virtuais do PROSSIGA (anexo 1). O Projeto PROSSIGA (Programa Informação para a Pesquisa) é uma iniciativa do $\mathrm{CNPq}$, cujo objetivo é favorecer e promover o uso da informação relevante para ciência e tecnologia, já disponível na internet ou em arquivos convencionais existentes em instituições brasileiras. $\mathrm{O}$ projeto utiliza a internet como meio para divulgação e uso dos seus serviços, procurando incentivar e favorecer a comunicação científica interativa. Entre outros serviços de informação, cria uma base de dados de trabalhos científicos produzidos pelos pesquisadores vinculados ao CNPq. Já dispõe de mais de 850.000 referências bibliográficas de mais de 13.000 pesquisadores. Conta com mais de 2.000 usuários cadastrados para discussão interativa em salas virtuais (TAKAHASHI 2000).

Um dos serviços do PROSSIGA são as Bibliotecas Virtuais Temáticas, que reúnem informações validadas de temas específicos, como a de Estudos Culturais, Economia, Óptica, Ciências Sociais, Saúde Mental e Saúde Reprodutiva, entre outras (Anexo 2).

O presente trabalho vai destacar a Biblioteca Virtual de Saúde Reprodutiva (BVSR), situada na internet na URL: www.prossiga.br/fsp_usp/saudereprodutiva (Anexo 3), criada em 1998 a partir de uma proposta do CNPq (Conselho Nacional de Desenvolvimento Científico e Tecnológico). Trata-se de um serviço desenvolvido pelo

\footnotetext{
* Sites ou sítios são conjuntos de páginas ou lugares no ambiente Web da internet, que são ocupados com informações (texto, fotos, animações, gráficos, sons, vídeos) de empresas ou pessoas. O nome por extenso é website.
} 
Departamento de Saúde Materno-Infantil e a Biblioteca/Centro de Informação e Referência da Faculdade de Saúde Pública da Universidade de São Paulo (USP) em parceria com o PROSSIGA/CNPq.

Os estudos sobre bibliotecas, inclusive as bibliotecas virtuais, fazem parte da área da Ciência da Informação, sendo um de seus objetos de estudo o acesso à informação institucionalizada, alterada significativamente com as mudanças ocorridas com o advento das novas tecnologias da informação. A informação passou do antigo conceito de documento para informação como objeto construído, selecionado, organizado. A Ciência da Informação estuda, entre outras, as questões da relevância da informação sobre o usuário e os aspectos cognitivos da geração e aquisição da informação e conhecimento (DIAS 2002).

O presente trabalho se propõe a discutir as tecnologias e as bibliotecas virtuais sob o contexto da ciência da informação e comunicação através da BVSR.

No $5^{\circ}$. Congresso Regional de Informação em Saúde, promovido pela BIREME em maio de 2001, houve a possibilidade de um contato com um dos principais filósofos da área de tecnologia da informação, o francês Pierre Lévy, que teoriza sobre as novas tecnologias, com questões levantadas a partir da junção da teoria da informação com a prática no trabalho de organizar e divulgar informações através do meio eletrônico.

No mundo atual sobra pouco tempo para reflexão sobre as mudanças tecnológicas que estão ocorrendo e suas implicações na sociedade, no ensino e na pesquisa. Será que elas estão sendo positivas? Desta forma um profissional da informação tenta colaborar para o desenvolvimento de uma reflexão sobre as tecnologias da informação e comunicação através da experiência com a BVSR. 


\subsection{Algumas Reflexões a Partir de Pierre Lévy}

Pierre Lévy, filósofo francês e professor da Universidade de Ottawa, analisa as mudanças antropológicas ocorridas na sociedade contemporânea com o advento da informática. Sua obra tem um enfoque bastante amplo, que perpassa as áreas dos estudos cognitivos, antropologia e educação. No presente trabalho será privilegiada a área da comunicação e da tecnologia da informação, abordadas em algumas de suas obras.

A partir da Revolução Industrial as áreas do conhecimento foram desenvolvendo suas técnicas, aplicadas na sociedade sem a devida análise das transformações que isso gerava na cognição e sem o desenvolvimento de projetos políticos e sociais. A questão técnica passa, então, a encaminhar uma revisão da filosofia política e revisitar a filosofia do conhecimento. Houve uma desestabilização da configuração dos saberes, que estava em equilíbrio desde a invenção da imprensa, no século XVI.

O conhecimento passou do oral ao escrito e ao informatizado e convivem na sociedade moderna. As articulações destes três tempos do espírito devem ser estudadas à luz da psicologia cognitiva e da história dos processos de inscrição. Não há um determinismo tecnológico, porém a técnica participa do condicionamento de certas evoluções culturais e deixa uma grande margem de interpretação para os protagonistas da história. A técnica abre algumas possibilidades, opções culturais e sociais (LÉVY 1993, 1999).

Os agentes efetivos das evoluções culturais são os indivíduos situados no tempo e no espaço, que interagem com as técnicas, considerando 'técnica' num sentido amplo de dimensão, ou seja, tudo o que passa por atores não humanos, como o alfabeto, meios de transporte, objetos, computadores, meios de comunicação entre outros. Além da linguagem o ser humano interage com a técnica para produzir conhecimento. 
LÉVY (1993) considera que a tecnologia e os homens formam a ecologia cognitiva - o homem interage com as coisas ao seu redor, criando novas tecnologias e mudando a sua forma de viver. O regime de produção e a distribuição do saber não dependem somente do sistema cognitivo humano, mas também da organização coletiva, dos instrumentos de comunicação e tratamento da informação (LÉVY 2000).

Neste contexto a comunicação na era da informática é estabelecida através de hipertextos, partilhados entre os atores, que modificam a configuração da mensagem de acordo com a rede de relações pela qual ela é capturada. Entenda-se por hipertexto um texto em formato digital, reconfigurável e fluido, composto por blocos elementares ligados entre si, que podem ser explorados em tempo real na tela. Engloba todas as categorias de signos, como imagens, sons, animações etc. (LÉVY 1999).

A comunicação para LÉVY (1993) também passou do pólo da oralidade, quando todos os parceiros faziam parte das mesmas circunstâncias, para o pólo da escrita, que mantinha uma distância grande entre o autor e o leitor, resultando numa objetividade e universalidade por parte do emissor e uma necessidade interpretativa do receptor. Finalmente, temos o pólo informático-mediático, onde os atores da comunicação dividem o mesmo hipertexto, diminuindo a pressão para a objetividade e universalidade, sendo as mensagens produzidas cada vez mais efêmeras.

A primeira função da comunicação é a transmissão de informações, mas o fundamento transcendental da comunicação é o hipertexto partilhado. Não é o contexto que esclarece o sentido de uma mensagem, mas sim o efeito da mensagem é que modifica, complexifica, retifica um hipertexto, criando novas associações em uma rede contextual anteriormente dada. $\mathrm{O}$ objeto de estudo deve ser o hipertexto, sistema sempre móvel das relações dos sentidos que os precedentes mantêm, não o emissor, a mensagem, o receptor. 
Os atores da comunicação e os elementos de uma mensagem remodelam universos de sentido, criando um mundo de significações que LÉVY (1993) chama de hipertexto, caracterizado por seis princípios abstratos:

1. Metamorfose - rede em constante construção e renegociação entre seres humanos e coisas.

2. Heterogeneidade - os nós da rede são heterogêneos, com inúmeras associações entre si, conexões lógicas, afetivas, multimídias etc.

3. Multiplicidade - organização de modo "fractal", cada nó ou conexão pode revelar-se como uma outra rede.

4. Exterioridade - a mobilidade de uma rede depende de elementos externos indeterminados, novas conexões, novos terminais, elétrons, raios $\mathrm{x}$ etc.

5. Topologia - a rede é o espaço, onde tudo funciona por proximidade, caminhos.

6. Mobilidade dos centros - numa rede cada nó pode ser um centro em determinado momento ou circunstância.

O hipertexto não é deduzido logicamente do texto fonte, ele é o resultado de uma série de decisões encaminhadas pela navegação. O leitor passa a ser um escritor na medida em que contribui para a redação de uma escrita interminável, seguindo os caminhos do sentido, recriando o texto mentalmente. O hipertexto opera a virtualização do texto, sendo toda a leitura uma escrita em potencial (LÉVY 1996, 1999).

Sobre o conceito de virtual LÉVY (1996) explica que virtual não se opõe ao real, mas sim ao atual. A informação é virtual por estar desprendida de um espaço e tempo. Ela é utilizada e interpretada e depois unida a outras informações para formar um sentido. Uma palavra é uma entidade virtual, pois não está em lugar nenhum e não se encontra vinculada a nenhum momento, porém ela existe de fato, não se opondo ao real. O virtual existe sem estar 
presente. Os sentidos de uma palavra são chamados de atualizações, o virtual é uma fonte indefinida de atualizações (LÉVY 1999).

LÉVY (1996) trabalha com quatro conceitos que se inter-relacionam dialeticamente: o potencial, o real, o virtual e o atual. A atualização é o oposto da virtualização. A atualização é a solução particular a um problema num dado espaço e tempo, é um acontecimento; enquanto que a virtualização é a passagem à problemática, parte de uma solução para levantar um problema, caracterizando-se também pela desterritorialização.

O virtual e o atual são acontecimentos de ordem de criação. O potencial e o real são substâncias de ordem de seleção. O real é a substância em si e o potencial é um conjunto de possibilidades existentes nesta substância. Trata-se de um poder.

No mundo contemporâneo os coletivos mais virtualizados e virtualizantes são os da tecnociência, das finanças e dos meios de comunicação. Está ocorrendo uma virtualização do corpo, a pessoa não está mais presente fisicamente nos lugares, ela trabalha à distância, há uma ampliação do uso de telefones e email (correio eletrônico), a pessoa faz parte de um corpo coletivo (LÉVY 1996).

O texto também está mais virtualizado, pois exige a subjetividade humana no uso do hipertexto.

A linguagem, a técnica e as convenções são processos de virtualização do humano. "A informática é a mais virtualizante das técnicas por ser, também, a mais gramaticalizante" (LÉVY 1996, p. 88).

A informação nas redes digitais encontra-se fisicamente situada em algum lugar e num determinado suporte, mas ela está virtualmente presente em cada ponto da rede onde é pedida. Isto ocorre com uma imagem ou um som, por exemplo, que passam por transformações de signos multiplicados 
indefinidamente. "O computador é, antes de mais nada, um operador de virtualização da informação" (LÉVY 1999; p.55).

A virtualização também é uma característica da própria comunicação, é a utilização da criatividade humana. A comunicação digital continua um movimento de virtualização iniciado há muito tempo pelas técnicas antigas como a escrita, a gravação de som, o rádio, a televisão e o telefone. Os novos dispositivos informacionais (mundos virtuais e informações em fluxo) e comunicacionais (comunicação "todos-todos") são os grandes portadores de mutações culturais (LÉVY 1999).

O desenvolvimento da comunicação assistida por computador e das redes digitais promoveu novas formas de inteligência coletiva, mais flexíveis e democráticas, fundadas na reciprocidade. A desterritorialização do virtual fez surgir um novo dispositivo de comunicação de coletividades chamadas "comunicação todos-todos" (LÉVY 1996, p.112). Como exemplo há Boletin Board (BBS), as salas de bate-papo* (chats), as listas de discussão etc.

Os meios de comunicação clássicos eram relacionamentos "um-todos" (televisão, jornal etc) ou "um-um", como o telefone, que não permitem uma visão global do contexto comum. Já no ciberespaço cada um é potencialmente emissor e receptor num espaço não-fixo. $\mathrm{O}$ encontro ocorre em centros de interesse, numa paisagem comum do saber.

Os processos de comunicação midiática antes da internet (TV, rádio, imprensa escrita) não provocavam o princípio da cooperação e nem contemplavam as diferenças culturais. Na fase pós-mídia, ou sociedade da informação, a interação não é mais despejar massas de informação, mas sim disponibilizar aberturas de comunicação para os indivíduos conquistarem a emancipação e participarem da inteligência coletiva. Entende-se por inteligência coletiva a relação dos saberes com as ações sociais, o diálogo que

\footnotetext{
* Salas de bate-papo ou chat caracterizam-se por sua informalidade, onde várias pessoas digitam o texto, estabelecendo um diálogo em tempo real, via páginas disponíveis na Web (FONTES 2001).
} 
fomenta a ação comunitária, que é a responsável pela coordenação do ato social (MEDEIROS 2001).

O entusiasmo pela internet está na sensação de mergulhar num cérebro comum, fazer parte de um interior caótico, fazer trocas em conjunto, participar das mudanças da inteligência coletiva, que se autocria, sem hierarquização. Por outro lado, a inteligência coletiva pode ser também negativa para a cibercultura, quando leva os sujeitos à sobrecarga cognitiva, à dependência (vício na navegação), à dominação, à exploração (teletrabalho vigiado) e à "bobagem coletiva", acúmulo de dados sem significação (LÉVY 1999).

COELHO (2001), comparando um livro de Pierre Lévy com um de Jean Baudrillard, observa que a visão de Lévy não fornece elementos para se compreender a dimensão contraditória da comunicação virtual, que proporciona uma abertura permanente da criatividade coletiva, mas, ao mesmo tempo, está sob o domínio de grandes provedores de informação, que detêm o poder de escolher o que se vai transmitir e de que forma. Ele cita exemplos, como o UOL, AOL, entre outros.

Desta forma, os provedores isentos de fins lucrativos, como os das universidades, precisam assumir o papel de não lucratividade e disponibilizar informações para o desenvolvimento da criatividade humana, colocada por Lévy. Ele considera que não é preciso banir o comércio na internet, mas sim preservar uma maneira original de construir coletivos inteligentes.

A inteligência coletiva para LÉVY (2000) é para onde caminha a humanidade, após a revolução da escrita, é uma nova dimensão da comunicação que permitirá o compartilhamento do conhecimento entre as pessoas e aumentará a chance de se ter uma vida melhor. Ele define inteligência coletiva como sendo "distribuída por toda parte, incessantemente valorizada, coordenada em tempo real, que resulta em uma mobilização efetiva das competências", tendo como base e objetivo "o reconhecimento e 
enriquecimento mútuos das pessoas, e não o culto de comunidades fetichizadas e hipostasiadas" (p. 28-9).

O homem caminha para o espaço antropológico do saber (LÉVY 2000). Espaço antropológico é um sistema de proximidade próprio do mundo humano, dependente de técnicas, linguagem, cultura, significações, representações de emoções. Um primeiro espaço foi a terra nos primórdios da humanidade (homo sapiens), caracterizado pela linguagem, técnica e organização social, com modos de conhecimento específicos, que são os ritos e mitos. O segundo espaço é o território, com a agricultura, a cidade, o Estado e a escrita e com modos de conhecimento representado pela escrita (saber sistemático, teórico ou hermenêutico).

O terceiro espaço antropológico é o das mercadorias, iniciado no século XVI, cujos princípios são os fluxos de energia, matérias-primas, capitais, mercadorias, mão-de-obra, informações. O modo de conhecimento é a ciência experimental moderna, que já começa a se desterritorializar em subordinação aos fluxos econômicos. Continuando, LÉVY (2000) considera que o próximo espaço é o do saber, que comandará os demais e se caracteriza pela velocidade na evolução das ciências e técnicas. O coletivo é quem vai criar e aprender, e as ferramentas são a informática e as técnicas de comunicação digital. Este novo espaço organiza-se a partir de dois eixos: "o da renovação do laço social por intermédio do conhecimento e o da inteligência coletiva propriamente dita" (LÉVY 2000; p. 26).

Muitos consideram utópica a visão de Lévy das tecnologias da informação. Ele utiliza palavras e expressões otimistas, como "tecnodemocracia", "inteligência coletiva", "sociedades pensantes", "dimensões da afetividade", "superlíngua", "espaço do saber” e outros. Ele próprio se considera um otimista, mas afirma que é preciso aproveitar estes acontecimentos tecnológicos e compreender a virtualização para evitar o sofrimento de submeter-se a ela sem conhecê-la. Considera que é preciso 
explorar as potencialidades mais positivas do ciberespaço nos planos econômico, político, cultural e humano.

\subsection{As Opiniões de Outros Teóricos}

Lucien SFEZ (1996b), filósofo francês, apresenta uma visão mais pessimista da comunicação na sociedade contemporânea. Para ele a história está chegando ao seu final, "o mundo está ficando velho" e caminhando cada vez mais da ideologia para a utopia, o que culminará na vida artificial, na saúde perfeita, no homem cibernético.

Segundo este autor a comunicação, que anteriormente tinha a sua força nas idéias, agora é comandada pelo extraordinário desenvolvimento das técnicas de comunicação e dos computadores. A comunicação tem-se baseado na lógica da oferta e não na lógica da demanda. As populações são orientadas a acreditar que as técnicas de informação e de comunicação vão dar sentido à vida.

Simbolizando a comunicação na era da utopia, SFEZ (1996b) indica que o herói comunicador vem a ser as técnicas e as tecnologias, as metáforas da máquina e do organismo, a racionalidade do homem normal, a ciência cognitiva e a inteligência artificial. Tudo isso visando à qualidade da ligação social. A principal conseqüência disso na realidade será o desmoronamento das crenças das populações dos países subdesenvolvidos, excluídos em razão da desigual repartição das tecnologias da comunicação.

A comunicação na era tecnológica é tautológica, ou seja, repetitiva (um jornal remete a um canal de TV e vice-versa, transmitindo a mesma mensagem) e autista, pois diante de tanta informação o receptor torna-se isolado, calado e auto-suficiente. SFEZ (1996a) juntou as duas palavras e criou a palavra "tautismo" para descrever a comunicação. 
Para SFEZ (1996a) a informação, ao chegar no receptor, passa pelas competências lingüísticas (linguagem que domina) e enciclopédicas (experiências de conhecimentos acumulados) do mesmo. Portanto a comunicação é circular, depende de como o receptor interioriza a informação, gera conhecimento ou saber. Uma forma de sair do "tautismo" da comunicação é interpretar a informação, ou seja, recompor a informação, mantendo um distanciamento entre o emissor e o receptor, e colocando uma pausa para a análise, a fim de resgatar o conhecimento acumulado na memória.

Para um outro autor, FASSLER (1998), professor da Universidade de Arte Aplicada de Viena, alguns marcos da natureza global do conhecimento da sociedade devem ser observados, como as estruturas das pesquisas empíricas, para se compreender a passagem da cultura abstrata para a cultura artificial.

Segundo ele, por dois séculos, as transformações tecnológicas ocorreram, mas foram ignoradas pelas ciências sociais e teoria da comunicação. A ordem abstrata era dividida, por um lado, pela intelectualidade e, por outro, pelas ferramentas mecânicas. A mídia, TV e máquinas desenvolveram-se de forma independente, com a finalidade de atender à necessidade de reprodução social, e as aplicações complexas da abstração (tecnologia computacional) conduziram para as transformações de redes artificiais e, consequentemente, à cultura artificial.

A cultura artificial, compreendida pela desmaterialização do mundo real, que pode ser criado através de "certos modelos matemáticos", é uma resposta do mundo. É um novo conceito de plasticidade, de ausência e presença, ou de territorialidade e globalidade, que abre um novo espaço social de hibridização para corpos virtuais e cultura virtual.

Esta tendência da cultura virtual leva à interdependência da tecnologia, inovações científicas, novos paradigmas para modelos mais complexos de informação e comunicação. A interface humano-computador é o fundamento 
para uma enorme transformação: este ambiente autoformativo é, ao mesmo tempo, comunicação e formação. Isto cria incansáveis espaços informacionais.

A informação é oferecida exaustivamente e a maior dificuldade passa a ser selecionar, interpretar e refletir sobre ela. Esta é uma questão de cultura, que deve ser levada em conta também nos cenários educacional e social.

A grande armadilha da evolução da mídia, segundo FASSLER (1998) é que termos como "aceleração" e "velocidade" transportam à idéia de uma tecnologia determinista. Para evitar este processo ele propõe o entendimento de cada e toda transformação tecnológica de forma integrada no processo sócio-cultural, como gesto da auto-observação e autoconstrução das redes de comunicação.

Outro escritor clássico da atualidade é o professor espanhol Manuel Castells. Sua obra prima "A Era da Informação" é uma coleção composta por três volumes extensos e repletos de informações sobre as mudanças sociais, políticas, culturais e econômicas, ocorridas no período da passagem de milênio, que leva a impossibilidade de se aprofundar sobre os seus pontos de vista em um número limitado de páginas.

CASTELLS (1999) aborda principalmente a revolução causada pelas tecnologias da informação, as crises econômicas do capitalismo e do estatismo e as profundas mudanças sociais.

A comunicação neste contexto de transformações se desloca com as conexões e desconexões das redes, levando a uma tensão crescente e à formação de grupos alienados.

Para CASTELLS (1999) a tecnologia não determina a sociedade e nem ocorre o inverso, trata-se de uma interação entre ambas. As esferas dominantes da sociedade difundem as tecnologias para o conjunto de relações e estruturas sociais, modificando-as e penetrando no poder e na experiência. $O$ 
desenvolvimento tecnológico modela o comportamento social, inclusive a comunicação simbólica, fazendo surgir novas formas de interação, controle e transformação social.

As tecnologias de informação, processamento e comunicação promoveram uma revolução na sociedade e têm grande poder por possibilitar uma realimentação entre a inovação e seu uso. Os usuários e criadores tornamse a mesma coisa.

CASTELLS (1999) apresenta as características do paradigma da tecnologia da informação:

- A informação é a matéria-prima das tecnologias

- A informação tem a capacidade de penetrar em todas as atividades humanas

- A lógica das redes passa a dominar, estruturada, porém flexível

- Maior flexibilidade, ou seja, a capacidade de se reconfigurar, mudar as organizações. CASTELLS (1999) observa que é necessário não confundir flexibilidade com força libertadora

- Convergência de tecnologias específicas para um sistema altamente integrado. Exemplo: a integração da microeletrônica, as telecomunicações, a optoeletrônica e os computadores integrados nos sistemas de informação.

A "mente alfabética" originou a transformação qualitativa da comunicação humana. $\mathrm{O}$ caráter da comunicação transformou-se significativamente quando foi possível integrar potencialmente o texto, a imagem e os sons num mesmo sistema, representado pela internet. Esta comunicação influencia a cultura e faz surgir a cultura da virtualidade real (CASTELLS 1999, p. 355). 
CASTELLS (1999) analisa a transformação da cultura de massa, desenvolvida por MacLuhan na década de 60, para o surgimento de redes interativas ou cultura da virtualidade real na atualidade. Segundo ele, MacLuhan discutia o fato de que a cultura de massa, principalmente a Televisão, transmitia as mensagens que eram absorvidas pelas mentes humanas de forma associativa/lírica, não envolvendo esforço psicológico ou raciocínio na análise da informação. Havia uma audiência homogênea de massa, um mundo de comunicação de mão-única, sem o feedback do público.

A partir dos anos 80, com as novas tecnologias, foi ocorrendo um processo de segmentação na audiência. A disponibilização de vídeo-cassetes, TV a cabo, jornais especializados, foram fragmentando a massa social e permitindo uma escolha por parte dos grupos.

Ainda assim, a comunicação continuava unidirecional, devido ao controle empresarial e institucional embutido. A interatividade só foi possível através do surgimento do computador, com a manifestação direta da audiência (CASTELLS 1999).

A internet surgiu como sistema de comunicação interativo e seu nascimento se deu através de, principalmente, dois dispositivos técnicos: o MINITEL francês e a ARPANET norte-americana. Ambos nasceram com objetivos institucionais, mas tornaram-se veículos de comunicação interpessoal, ampliando-se no mundo e culminando com a internet. A internet surge de uma mistura de estratégia militar, grande cooperação científica e inovação contracultural, tornando-se independente de centros de comando e controle (CASTELLS 1999).

A comunicação mediada por computador se desenvolve resgatando a mentalidade da tipografia e a recuperação do discurso racional. Muitas pesquisas revelam que, apesar de todo o entretenimento oferecido pelas redes, a grande demanda dos usuários é para o acesso à informação e para questões comunitárias (CASTELLS 1999). 
CASTELLS faz uma previsão sobre as consequiências das tecnologias na cultura da sociedade da informação:

- Centralidade na casa e individualismo. As residências equipadas eletronicamente estão se tornando mais atraentes, e as pessoas ficando mais tempo em casa. Ao mesmo tempo, alguns costumes e tradições das culturas estão absorvendo os meios de comunicação eletrônicos, como o karaokê, por exemplo.

- Crescente estratificação social entre os usuários. Há duas populações distintas: a interagente e a receptora da interação.

- Integração de todas as mensagens em um padrão cognitivo comum, mistura aleatória de vários sentidos.

- A multimídia capta em seu domínio a maioria das expressões culturais em toda a sua diversidade: imprensa, audiovisual, cultura popular e erudita, entretenimento, informação etc.

Partindo de conceitos clássicos, desenvolvidos por Roland Barthes e Jean Braudillard, de que a cultura é formada por processos de comunicação e que as formas de comunicação são baseadas na produção e consumo de sinais, pode-se dizer que está emergindo a cultura de virtualidade real (CASTELLS 1999). Virtual para CASTELLS (1999) é o que existe na prática e real é o que existe de fato. "Todas as realidades são comunicadas por intermédio de símbolos e na comunicação interativa humana, independentemente do meio, todos os símbolos são, de certa forma, deslocados em relação ao sentido semântico que lhes é atribuído. De certo modo, toda realidade é percebida de maneira virtual" (p. 395).

As bases principais da nova cultura são o espaço de fluxos e o tempo intemporal. As redes de comunidades virtuais são efêmeras, a contribuição dos participantes é esporádica, as pessoas entram e saem das redes de acordo com os interesses e expectativas não satisfeitas. CASTELLS (1999) coloca uma 
hipótese de que uma minoria usa meio eletrônico com regularidade e uma multidão transitória usa as redes para explorar modalidades efêmeras.

Para o teórico da informação português Adriano RODRIGUES (1994), a comunicação serve para legitimar discursos, comportamentos e ações, sendo um instrumento mobilizador que instaura consensos.

Atualmente, na sociedade da informação, cabe à ideologia comunicacional redefinir um novo tipo de racionalidade, que tem se mostrado ao mesmo tempo racionalista e anti-racionalista, na medida em que impõe leituras. Falta formalização teórica dos seus princípios lógicos. Ao mesmo tempo em que retorna à cultura tradicional da oralidade e informalidade, usa um discurso baseado em razões técnico-científicas.

A informação é uma dimensão diferente da comunicacional, apesar de serem muito confundidas devido à ideologia tecnocrática. Essa diferenciação se evidencia no fato de, apesar da globalização da informação, ainda assistirmos à persistência dos regionalismos, nacionalismos e fundamentalismos. Existem duas esferas distintas para RODRIGUES (1994):

- a da informação, que é uma realidade relativa, compreendida como o conjunto dos acontecimentos ocorridos no mundo e formadores do nosso meio ambiente. Os acontecimentos são tanto mais informativos quanto menos previsíveis. Quando uma mensagem integra o núcleo de mensagens socialmente aceitas numa sociedade o seu valor vai diminuindo. $\mathrm{O}$ processo da informação não é recíproco nem reversível, é a transmissão unilateral de uma mensagem para destinatários, que se supõe, desconhecê-la.

- a comunicacional, que é um processo que ocorre entre pessoas dotadas de razão e liberdade pelo fato de pertencerem a um mesmo mundo cultural. É um processo relativamente previsível e reversível, com troca simbólica generalizada. A comunicação se amplia para 
além dos núcleos de cultura através dos meios de informação, estabelecendo, assim, relações entre a esfera informativa e o domínio da comunicação.

É preciso distinguir a esfera da informação do domínio cultural da comunicação, pois, apesar da percepção da realidade ter se tornado um produto tecnicamente elaborado pelos mídia, cada indivíduo continua a interpretá-la no quadro da experiência espontânea da própria cultura.

Na comunicação humana o homem responde aos estímulos através de respostas virtuais, ou através da "pulsão". Ele se relaciona com outros homens por meio de signos culturais concebidos por ele próprio, mesmo sem ter recebido estímulo. O homem comunica, inventando mediações simbólicas (RODRIGUES 1994).

\subsection{A Exclusão Digital}

Juntamente com o desenvolvimento da tecnologia da informação, e talvez ocasionado por esta, surgiu no contexto social o personagem excluído dessa moderna sociedade da informação. Prega-se que foi criado um "abismo digital", que aumenta a segregação e a desigualdade social, dando oportunidade somente para a população que domina a tecnologia e tem acesso à informação.

Questiona-se, porém, se não há exagero nessas ponderações. O jornalista SAMUELSON (2002) mostra, em artigo sobre abismo digital, que pesquisadores americanos têm observado que o aumento das diferenças sociais nos Estados Unidos surgiu antes do advento da informática e outros estudos têm apontado que o abismo entre grupos de diferentes etnias está sendo cada vez menos significativo. As pesquisas têm indicado que não há relação direta e 
comprovada entre as taxas de desemprego e o analfabetismo tecnológico das populações.

No mesmo artigo o autor comenta que, apesar das escolas americanas terem em 2000 por volta de um computador para cada quatro alunos, não houve nenhuma melhora na perspectiva de vida desses alunos. $\mathrm{O}$ ato de utilizar a internet é considerado simples, bastando direcionar e clicar. As dificuldades aparecem quando há a necessidade de leitura e interpretação de textos. "O abismo digital propõe uma solução simples (computadores) para um problema complexo (pobreza)" (SAMUELSON 2002, p.b6).

VOGT (2002), também jornalista, faz uma comparação divertida entre o homem digital e um cão: eles não são nem incluídos nem excluídos. Ele explica que os teóricos idealizadores da sociedade de informação orgulham-se ao dizer que há inclusão digital das populações do planeta, devido às facilidades eletrônicas e ao conceito de universalização inerente à internet. Porém, o abismo digital continua aumentando e uma grande multidão permanece excluída do acesso, seja aos bens de consumo, seja às condições de desenvolvimento cultural humanístico.

O governo brasileiro tenta criar condições para que haja crescente confiança pública no novo contexto da sociedade da informação. A inclusão social informatizada tem sido fomentada para permitir o uso da internet para fins de ensino e pesquisa. Para cumprir os acordos e participar do programa internet 2, o governo brasileiro lançou em 1999, através do Conselho de Ciência e Tecnologia, o documento "Ciência e Tecnologia para a Construção da Sociedade da Informação" e, em setembro de 2000, o "Livro Verde da Sociedade da Informação" (VOGT 2002).

O Livro Verde foi apresentado à sociedade pelo Ministério da Ciência e Tecnologia para ampla divulgação e debate. Ele contém as metas de implementação do Programa Sociedade da Informação e constitui uma súmula consolidada de possíveis aplicações de Tecnologias da Informação. Esse livro 
contempla um conjunto de ações para impulsionar a Sociedade da Informação no Brasil, em todos os seus aspectos: ampliação do acesso, meios de conectividade, formação de recursos humanos, incentivo à pesquisa e ao desenvolvimento, comércio eletrônico, desenvolvimento de novas aplicações. Esta meta é um desafio para o Governo e para a sociedade (TAKAHASHI 2000).

Nesse livro observa-se a preocupação com o surgimento de uma nova lógica de exclusão, acentuando as desigualdades e exclusões já existentes, tanto entre sociedades, como no interior de cada uma, entre setores e regiões de maior e menor renda. No novo paradigma, a universalização dos serviços de informação e comunicação é condição necessária, ainda que não suficiente, para a inserção dos indivíduos como cidadãos, não bastando proporcionar a infra-estrutura moderna, mas também dando condições para transformar a informação em conhecimento.

Da mesma forma, não basta disponibilizar uma quantidade enorme de informação, se a população não tem a capacidade de dela apropriar-se e fazer uso para a melhora de sua qualidade de vida (SMIT 2002).

Na era da internet, o Governo deve promover a universalização do acesso e o uso crescente dos meios eletrônicos de informação para gerar uma administração eficiente e transparente em todos os níveis. Cabe ao sistema político promover políticas de inclusão social, para que o salto tecnológico tenha paralelo quantitativo e qualitativo nas dimensões humana, ética e econômica. A chamada "alfabetização digital" é elemento-chave nesse cenário.

O Programa Sociedade da Informação para se concretizar precisa contar com a colaboração das universidades e demais entidades educacionais, envolvidas na formação de recursos humanos e na construção da indispensável base científico-tecnológica do país. Essa iniciativa permitirá alavancar a pesquisa e a educação, bem como assegurar que a economia brasileira tenha 
condições de competir no mercado mundial. O Livro Verde, após amplas discussões e propostas, será consolidado no Livro Branco.

O Livro Branco (MINISTÉRIO DA CIÊNCIA E TECNOLOGIA 2002) apresenta os resultados da Conferência Nacional de Ciência, Tecnologia e Inovação (C,T \& I), ocorrida em setembro de 2001, e tem por objetivo apontar os caminhos para que a C,T \& I possam contribuir para a construção de um país mais dinâmico, competitivo e socialmente mais justo. Este livro pretende indicar os rumos para os próximos 10 anos (até 2012).

O Livro Branco examina os principais desafios para a consolidação de um Sistema Nacional de C,T \& I para que o país possa criar condições de desenvolvimento sustentável, apresentando uma proposta de política com as bases para a formulação de diretrizes estratégicas com vistas às ações necessárias para que se alcancem os objetivos visados.

Observa-se que está havendo um crescimento significativo na telefonia no Brasil e no número de conexões de computadores na internet. A FUNDAÇÃO IBGE (2002a) divulgou que os Serviços de Telecomunicações representavam 68\% da receita dos Serviços de Informação em 2002, sendo que em 2001 essa participação era de 67,4\%. Até mesmo populações faveladas já estão tendo acesso a telefones celulares, televisores, e até computadores. Mesmo estando longe de atingir a população miserável brasileira, pode-se observar um certo avanço nessa área.

O Censo de 2000 do IBGE (FUNDAÇÃO IBGE 2002b) informa que, apesar da melhoria dos indicadores de consumo, há computadores em apenas 10,6\% dos domicílios brasileiros. Nas grandes cidades há computadores em 19,6\% dos domicílios, sendo que nos municípios pequenos com até 20 mil habitantes este percentual cai para $2,7 \%$.

Na mídia televisiva têm-se verificado manifestações solidárias que contribuem para a inclusão digital, como campanhas de doação de 
microcomputadores para as escolas. Outro fenômeno ocorrido nas periferias da cidade de São Paulo é o do micro-vizinho, em que são instalados micros em algumas casas e compartilhados por pessoas vizinhas.' O Comitê para Democratização da Informática tem facilitado a instalação de microcomputadores em favelas do Rio de Janeiro e ensinado a população a utilizá-los, formando alunos que se tornam professores num processo de multiplicadores da informação.

Muito se tem feito para diminuir a exclusão digital, mas há muito ainda a se fazer para tirar numerosos grupos sociais do abandono e isolamento, como previu FASSLER (1998). Será necessário um processo de adaptação da aprendizagem para as pessoas poderem participar da cultura artificial de forma plena e ativa.

Para CASTELLS (1999) a comunicação mediada por computadores não é um meio de comunicação geral, ela ainda excluirá a maior parte da humanidade por um longo tempo. Em comparação com outro meio, como a Televisão, que atingiu mais rapidamente as várias camadas sociais, verifica-se que este é um meio que não demanda instrução para sua utilização. Portanto, a exclusão não ocorre somente devido à falta de poder aquisitivo, mas também pela falta de instrução de grande parte da população.

CASTELLS (1999) prevê que a comunicação mediada por computador vai se expandir em ondas, partindo das elites, principalmente via sistema educacional.

\section{INTERNET E PESQUISA ACADÊMICA}

A internet foi introduzida no Brasil em 1989, através da Rede Nacional de Pesquisa (RNP). A história da internet nos meios acadêmicos no Brasil,

\footnotetext{
* Programa SPTV de 03 mai 2002, na Rede Globo de Televisão
} 
apesar de breve, está numa etapa avançada. A maior parte dos pesquisadores já entrou em contato com redes digitais e tem diferentes graus de familiaridade com sua utilização, muitas vezes frustrante (CUENCA 2004).

No entanto, devido ao forte uso da internet, sua estrutura técnica precisou ser ampliada e atualizada na rede acadêmica brasileira com a construção de um backbone de alta velocidade, conhecido como internet 2. A internet 2 ou Rede Nacional de Pesquisa 2 tem por objetivo final interligar a comunidade acadêmica brasileira à rede internet 2 norte-americana e assim aliviar o fluxo na rede para a Academia, separando-a da internet comercial, iniciada em 1995, e que está sobrecarregada (CUNHA 2000).

A ciência é uma atividade essencialmente comunicativa, pois, além de precisar de informações para ser produzida, a produção efetiva só ocorre após a divulgação, aceitação e uso pela comunidade acadêmica. Desta forma espera-se que uma ferramenta tão potente como a internet seja rapidamente introduzida no meio acadêmico. No entanto, conforme discorre ITURRI (1998), verifica-se subutilização de computadores e desconfiança de boa parte do meio acadêmico, devido a dificuldades, como custo elevado, problemas na instalação, resistência ao uso desta tecnologia que lhes demanda muito tempo e esforço, em comparação aos resultados alcançados. Também são citados os temores e fobias, faixa etária avançada e percepção de que a internet é mais desenvolvida para o comércio.

Segundo CUNHA (2000) está ocorrendo uma mudança no objeto central das universidades e faculdades: o enfoque está passando do corpo docente para o corpo discente. Ele prevê que, nos próximos anos, devido ao aumento na demanda para cursos de nível superior, haverá também uma expansão do mercado competidor, que passará a oferecer novas formas de aprendizado, diferentes do tradicional.

Dados estatísticos do Instituto de Estudos e Pesquisas Educacionais (INEP) apresentam um crescimento de institutos de ensino superior 
particulares, observando-se que ainda há uma demanda reprimida pelos cursos de graduação (CUNHA 2000).

Neste novo paradigma, como chama CUNHA (2000), a tecnologia tem presença garantida e, com ela, a internet. Os estudantes de hoje fazem parte de uma geração digital acostumada à interatividade e não a uma participação passiva como era até então, com os meios de comunicação tradicionais (rádio, TV). Os estudantes dos próximos anos vão requerer diferentes formas de educação, com um aprendizado interativo e colaborativo.

\subsection{As Bibliotecas Virtuais}

As transformações tecnológicas que estão ocorrendo, como já foi visto, interferem no modo de vida, nas formas de pensar e, consequentemente, na maneira de manipular, armazenar e distribuir a informação.

As bibliotecas têm passado sobremaneira por essa transição. Até então o material impresso era o seu objeto. As preocupações estavam voltadas para o armazenamento, conservação e organização das publicações. A forma de recuperação do material bibliográfico era feita através de fichas catalográficas impressas, manuseadas pelos usuários.

LANCASTER (1994), considerando as inovações tecnológicas, dividiu em dois grupos as atividades das bibliotecas, afetadas pela tecnologia: as de controle de inventário e as de recuperação de assunto. No primeiro grupo encontram-se as atividades de registro de coleções e controle de circulação e, no segundo, onde se verificam as mudanças mais significativas, observam-se o acesso às informações através de catálogos eletrônicos, bases de dados bibliográficas, numéricas, textuais, bem como o desenvolvimento de interfaces mais amigáveis de recuperação de dados. 
A "filosofia" da biblioteca passou da propriedade para o acesso à informação e as bibliotecas passaram a ser avaliadas pelos serviços que fornecem e não pelos acervos que abrigam (LANCASTER 1994).

Com a internet e sua infinidade de informações, as bibliotecas encontram o desafio de cumprir o seu papel de organizar essas informações para levá-las até o seu usuário de uma forma mais rápida e com resultado satisfatório. A diferença é que nos dias atuais nem os profissionais da informação têm noção da quantidade e volatilidade da informação disponível na internet.

Para LEVACOV (1997, p.132) "a função principal da biblioteca tem sido a de manter a memória coletiva da sociedade" que, com a internet, tornou-se uma memória distribuída e em constante transformação. Encontrar as informações, desenvolver políticas para identificá-las e indexá-las, promover o compartilhamento destas informações e agregar valor com a intenção de atender às comunidades virtuais representam um dos maiores desafios aos bibliotecários na época atual.

O objetivo final das bibliotecas é levar informações aos usuários. Para refletir sobre esse processo, BARRETO (1996, p.132) conceitua informação "como um instrumento modificador da consciência do homem e seu grupo social". Para estabelecer uma relação entre informação e conhecimento é necessário que ela seja percebida e aceita, ou seja, assimilada. A essência da informação é a adequação de um processo de comunicação que se efetiva entre o emissor e o receptor da mensagem (BARRETO 1994).

O mesmo autor discorre sobre a oferta e a demanda da informação, colocando que a oferta "determina a demanda por informação" (BARRETO 1996, p.6), ao contrário do que ocorre na economia, cujo mercado ajusta-se dependendo da demanda. 
Centros de informação, bibliotecas, redes de informação, museus e, por conseguinte, as bibliotecas virtuais são chamados por BARRETO (1994; 1996) de "agregados de informação" ou "estoques de informação". Os agregados de informação aumentam as condições de produção de informação, mesmo sem um acréscimo na demanda, ou seja, uma biblioteca expande suas coleções independentemente da procura pelos usuários. Isto segue a lógica natural dos acervos das bibliotecas, sejam elas tradicionais ou virtuais.

Aquele que detém o estoque da informação procura disponibilizá-la amplamente para maximizar o seu uso sem que, em alguns casos, sejam considerados a qualidade da informação e o interesse dos indivíduos por essa informação. Porém, BARRETO (1996) observa que, apesar da oferta determinar a demanda, não pode transformar esta demanda em conhecimento, pois não existe o poder dessa informação promover uma ação.

De qualquer forma as instituições ou, especificamente, as bibliotecas virtuais têm um compromisso com a qualidade da informação em termos de novidade, confiabilidade e cobertura das áreas temáticas, que justificam a sua importância para os usuários.

As bibliotecas virtuais, assim como as bibliotecas tradicionais e os sistemas de informação, utilizam a informação como objeto e, a partir dele, elaboram outras informações para descrevê-lo e representá-lo. BUCKLAND (1991, p.351) chama a informação produzida pelos sistemas de informação de "informação como coisa".

Há que se considerar que a informação produzida pelas instituições para representar outras informações tem um caráter determinista, uma vez que atribui uma função na organização da informação e segue padrões nem sempre de acordo com o conhecimento dos usuários.

Segundo SMIT (2002), as instituições disponibilizam dois tipos de informação: a contida nos documentos e a gerada pela instituição coletora de 
cultura, a informação documentária. Esta última é montada a partir de códigos que, muitas vezes, não servem para mediar a informação com o usuário. As instituições têm apresentado duas soluções para o problema: treinar o usuário nesses códigos ou adequar a informação documentária a ele. O usuário, dessa forma, deixa de ser um sujeito passivo para se tornar um agente ativo, um consumidor.

Se houvesse a possibilidade de conhecer a demanda de informação dos usuários e adequá-la à organização das bibliotecas, estas seriam mais eficientes. No caso das bibliotecas virtuais, a internet facilita a comunicação interativa com o usuário, qualificando essa forma eletrônica de comunicação. O que se faz necessário é efetivar a comunicação.

Ainda não se chegou a um consenso quanto ao conceito de biblioteca virtual, embora seja bastante discutido na literatura. $\mathrm{O}$ mesmo acontece com as denominações: biblioteca eletrônica, biblioteca polimídia, biblioteca digital, biblioteca virtual, biblioteca do futuro, entre outras. Porém, observa-se que os termos mais utilizados são biblioteca virtual e biblioteca digital, por serem mais abrangentes e utilizarem variada quantidade de tecnologias de comunicação e informação (OHIRA e PRADO 2002).

Vários autores vêm tentando conceituar biblioteca virtual, alguns deles, como MACEDO e MODESTO (1999) consideram esse termo com insegurança, devido à falta de um posicionamento paradigmático e ainda pela ambigüidade das definições. Os processos inovadores estão colocando em plena transformação os ambientes da informação.

MACEDO e MODESTO (1999) afirmam que a biblioteca virtual é aberta, flexível e não presencial, e que depende de recursos complexos de tecnologia de realidade virtual.

Em 1997, um número especial da revista CIÊNCIA DA INFORMAÇÃO, apresenta vários trabalhos sobre biblioteca virtual, como 
conceitos, relatos de experiência, as medidas adotadas pelas instituições para promoção das bibliotecas virtuais e outros trabalhos pertinentes que permitem desenvolver um quadro teórico do tema. O termo biblioteca virtual era comumente utilizado e esta temática estava em pleno dinamismo, com o conhecimento em construção e propostas de questionamentos e reflexões, de modo a estabelecer consensos e diretrizes.

A evolução da biblioteca de acordo com a tecnologia que utiliza é colocada por CUNHA (2000) nas seguintes eras:

1. Tradicionais - utilizam o papel como suporte de registro da informação

2. Automatizadas - utilizam o computador para serviços básicos de registro da informação, como catalogação, indexação etc.

3. Eletrônicas - utilizam o CDRom para recuperar referências bibliográficas e textos completos

4. Digitais - não necessitam de espaço físico, o acervo está digitalizado e disponível na internet

5. Virtuais - acrescentam às digitais os serviços no modo virtual, usa recursos da realidade virtual e a comunicação com os usuários passa a ser por meio eletrônico

Para o presente trabalho será adotado o conceito de biblioteca virtual utilizado pelo PROSSIGA, ou seja, uma página hipertextual, desenvolvida em linguagem HTML (Hypertext Markup Language), abrigada em um servidor internet e acessível através do protocolo HTTP. Utiliza a metodologia SGBV Sistema de Gerenciamento de Bibliotecas Virtuais - para dar suporte ao armazenamento e recuperação de dados (CHASTINET 1999). Acrescenta-se que os serviços oferecidos aos usuários, como boletins eletrônicos, respostas aos emails e cadastros institucionais e pessoais são feitos por meio eletrônico também. 
O principal objetivo das bibliotecas virtuais do PROSSIGA é "promover o uso da informação disponível na internet para comunidades envolvidas com atividades de pesquisa, nos temas prioritários do CNPq, assim como disponibilizar na rede a informação nacional considerada mais relevante pelos pesquisadores" (GOMES e col. 1996, p.3).

\subsection{A Comunicação na Área das Bibliotecas Virtuais}

Segundo RODRIGUES (1994) há três modelos de comunicação coexistindo atualmente: o tradicional, baseado na oralidade e nas práticas ritualísticas; o moderno, apoiado na escrita e na racionalidade, e o eletrônico ou em rede.

A comunicação em rede tem a informação eletrônica como essência (BARRETO 1994). Nas bibliotecas virtuais os receptores da informação são heterogêneos, vinculados em condições diferenciadas de classes sociais, gênero, raça e religião. Para atender a abrangência da informação, os produtores aumentam continuamente os estoques para transferir a informação de acordo com três estratégias:

- Atingir e criar grandes grupos homogêneos de receptores - menor conhecimento para maior número de receptores

- Identificar interesses e necessidades comuns de informação para grupos diferenciados - maior conhecimento para grupo reduzido

- Privilegiar uma elite informacional - maior conhecimento para uma elite

Para democratizar a informação é necessário, além de facilitar e aumentar o acesso, dar condições aos indivíduos para compreendê-la, ou seja, tornar as bibliotecas virtuais atraentes e fáceis de manipular. 
BARRETO (2001) discorre sobre os fluxos da comunicação nas culturas primitivas ou tribais, na cultura moderna da escrita e da imprensa e na cultura da revolução da informação, ou pós-moderna.

$\mathrm{Na}$ comunicação eletrônica direta, ou seja, numa situação de comunicação do usuário com a biblioteca virtual, BARRETO (2001) levanta as seguintes características:

- O receptor abandona a sua posição de distanciamento com relação ao fluxo da informação e passa a participar mais diretamente, sem intermediários

- A interação tende a ocorrer em tempo real e a avaliação da informação é imediata

- O receptor recebe a informação de modo não-linear, ou seja, ela vem associada às condições de um hipertexto, expressa de forma polivalente (texto, imagem, som...)

- Há maior facilidade para mudar de um estoque de informação para outro, ou seja, há desterritorialização.

- Há maior velocidade no acesso à informação

- Existe menor ocultamento da informação, devido à possibilidade do usuário fazer buscas mais livremente, sem estar preso aos instrumentos de metalinguagens e universos semânticos privados.

Quanto à comunicação entre os usuários das bibliotecas virtuais e os mediadores da informação (bibliotecários, cientistas da informação), também chamado de serviço de referência e informação para o usuário remoto, vale considerar outro trabalho de MACEDO e MODESTO (1999), que adaptam cinco linhas do serviço de referência de uma biblioteca tradicional para as bibliotecas virtuais, como relacionado a seguir: 
- Interação humana, apesar de não ser mais face-a-face, ocorre troca de email, telefonemas, comunicação em salas de bate-papos, videoconferência e outros. É importante manter este caráter humanizante no uso das tecnologias.

- Educação do usuário - orientação ao usuário sobre os instrumentos utilizados para organizar a informação e como utilizá-los. Nas bibliotecas virtuais pode ser utilizada a metodologia da educação à distância.

- Alerta e disseminação da informação - produtos programados para atualizar e divulgar o conhecimento. Podem ser exemplificados pelos boletins eletrônicos, disponibilizados nas páginas das bibliotecas virtuais ou remetidas aos usuários através do email.

- Divulgação e comunicação visual - trata-se do layout das páginas eletrônicas das bibliotecas virtuais e instruções de uso e divulgação dos serviços disponíveis.

- Administração e supervisão do serviço de referência - organização do site e atualização das informações periodicamente.

Um exemplo dessas características ocorrendo em biblioteca tradicional simultaneamente à virtual é o caso da Biblioteca/CIR da Faculdade de Saúde Pública. Esta biblioteca é considerada híbrida, conceito definido por OHIRA e PRADO (2002) e MACEDO e MODESTO (1999), como sendo uma biblioteca que possui acervo real somado aos serviços remotos, com os usuários distribuídos entre o fisicamente presente e o remoto, que podem optar pelos serviços locais de atendimento às dúvidas, orientação no uso do acervo, na normalização de referências entre outros, que estão disponíveis também via internet.

A experiência vivida no Serviço de Acesso à Informação da Biblioteca da FSP aponta, nos últimos anos, para uma ampliação no número de usuários 
remotos, após a inclusão dos serviços eletrônicos (CUENCA e col. 2003). Assim, através de email, pode-se observar que é possível uma comunicação interativa com os usuários, facilitada com o uso dos recursos da internet. Pesquisadores e estudantes de todo o Brasil e alguns de outros países entram em contato com a Biblioteca para buscar informações sobre publicações, catálogos, bases de dados bibliográficas, assuntos de interesse, entre outros.

A comunicação nas bibliotecas virtuais, em resumo, objetiva facilitar a geração de conhecimento nos indivíduos e no seu espaço social, fazendo com que ele possa produzir informações, formando assim um ciclo da informação.

\section{A BIBLIOTECA VIRTUAL DE SAÚDE REPRODUTIVA}

\subsection{Conceito de Saúde Reprodutiva}

O conceito de saúde reprodutiva surgiu a partir do conceito de saúde da mulher e de saúde materna. Primeiramente o enfoque estava no controle da fecundidade das mulheres de forma implícita, pois o governo brasileiro não tinha adotado oficialmente uma política de controle do crescimento populacional. O governo era pressionado para este controle pelos países desenvolvidos e, paralelamente, o movimento de mulheres, juntamente com cientistas sociais e profissionais da saúde, também cobrava uma assistência à saúde integral da mulher e não somente centrada na fecundidade (OSIS 2001).

Diante das pressões o governo criou o Programa de Assistência Integral à Saúde da Mulher (PAISM) em 1983, com a finalidade de atendimento à saúde reprodutiva das mulheres e não mais à utilização de ações isoladas de planejamento familiar. Segundo OSIS (2001), a proposta original do PAISM 
contempla a definição de saúde reprodutiva adotada pela Organização Mundial da Saúde, em 1988, e consolidada no Cairo, em 1994.

A linguagem e os conceitos relativos à saúde da mulher e do homem foram evoluindo ao longo dos anos e aglutinando outros conceitos, como controle da natalidade, controle populacional, planejamento familiar, saúde reprodutiva, saúde sexual, entre outros (GALVÃO 1999).

A participação dos profissionais da saúde, cientistas sociais e do movimento organizado de mulheres foi muito importante no desenvolvimento destes conceitos, com bases em suas experiências na prática médica, na elaboração de programas e pesquisas e na atuação social dos movimentos.

GALVÃO (1999) apresenta algumas definições para saúde reprodutiva que aparecem na literatura da área. Uma delas é a de Evans e colaboradores, datada de 1987: "a habilidade da mulher de viver desde a adolescência ou casamento, o que vier primeiro, até a morte, com escolha reprodutiva, dignidade e maternidade bem-sucedida e viver razoavelmente livre de doenças e riscos ginecológicos" (p.170).

Já para Fathalla (1988), citada também por GALVÃO (1999), saúde reprodutiva significa que as pessoas possam reproduzir-se e controlar a fertilidade com conhecimentos adquiridos, que as mulheres tenham acesso à maternidade segura, que a gravidez possa ocorrer com segurança para a mãe e o feto e que os casais possam ter uma vida sexual saudável. Esta definição foi amplamente utilizada pela Organização Mundial da Saúde.

Segundo Germain e Antrobus, 1989, citados por GALVÃO (1999, p. 170) saúde reprodutiva é "a habilidade de desfrutar das relações sexuais sem medo de infecção, gravidez não desejada, ou coerção; de regular a fertilidade sem risco de efeitos colaterais perigosos ou não desejados; ter acesso à maternidade segura; ter gestações e criar crianças saudáveis". 
O conceito de Saúde Reprodutiva evoluiu e adquiriu expressão como área de conhecimento desde 1994 na Conferência Internacional sobre População e Desenvolvimento, realizada no Cairo. Neste evento Saúde Reprodutiva foi definida como um estado de completo bem-estar físico, mental e social em todas as matérias concernentes ao sistema reprodutivo, suas funções e processos, e não a simples ausência de doença ou enfermidade. A saúde reprodutiva engloba a saúde sexual, envolvendo o direito de homens e mulheres às informações sobre métodos seguros e aceitáveis para o planejamento familiar e aos serviços de saúde, que garantam uma gestação e parto seguros (BILAC e ROCHA 1998).

Este conceito ganhou amplitude, após esta conferência, por incluir a saúde sexual e, por conseguinte, os assuntos relacionados à Aids, às doenças sexualmente transmissíveis e às questões referentes à saúde do homem.

A saúde reprodutiva se desdobra nas discussões das questões de gênero e direitos reprodutivos. Reconhece os direitos reprodutivos como parte dos direitos humanos, condenando as discriminações, formas de coação e violência, que interfiram na reprodução. $\mathrm{O}$ conceito de gênero é retomado e ampliado para as diferenças percebidas entre sexos nas sociedades e não considerado somente como as diferenças biológicas sexuais.

Cabe destacar que o Brasil se colocou numa posição progressista na Conferência do Cairo e a delegação brasileira teve uma participação ativa, reconhecida pelos participantes do evento. Houve um consenso entre os posicionamentos oficiais brasileiros $\mathrm{e}$ os das organizações nãogovernamentais, o que colaborou para o destaque brasileiro na participação no evento (ALVARENGA e SCHOR 1998).

A Conferência da Mulher em Beijing, em 1995, um ano depois de Cairo, enfatizou ainda mais o enfoque de igualdade de gênero e direitos reprodutivos. 
Passados cinco anos após a Conferência de Cairo, a ONU organizou reuniões para fazer um balanço sobre a situação da saúde reprodutiva. Estas reuniões culminaram no evento Cairo +5 , ocorrido na Assembléia Geral da ONU, em Nova Iorque, que, apesar de muitos desencontros entre a ala católica e a ala das feministas mais radicais, gerou um documento final (ABRACINSKAS 1999).

Os pontos mais discutidos neste evento foram saúde sexual, saúde dos adolescentes e aborto (CORREA 1999). São temas polêmicos que geram discussões de cunho político, biológico, sociológico, antropológico, psicológico, religioso, demográfico e do direito.

BILAC e ROCHA (1998) consideram a saúde reprodutiva pelas suas características repletas de questionamentos e transdisciplinaridades "um apaixonante objeto de pesquisa" (p.14). Esta área temática articula várias teorias, vários objetos, cada qual demandando um tratamento específico com problemáticas particularizadas.

Porém, para além da discussão, o desafio que se coloca atualmente "é uma maior difusão, expansão e adoção efetiva destes conceitos" (GALVÃO 1999, p.177)

\subsection{Sobre a Proposta da Biblioteca Virtual de Saúde Reprodutiva (BVSR) e sua Implementação}

O Programa PROSSIGA de bibliotecas virtuais temáticas adotou como premissas básicas que o uso da internet é uma realidade, que existe o compromisso de introduzir e fomentar a informação brasileira sobre ciência e tecnologia na internet e que uma tecnologia da inteligência pode contribuir para a criação intelectual (GOMES e CHASTINET 1997). Assim, a Biblioteca Virtual de Saúde Reprodutiva faz parte do rol das bibliotecas virtuais temáticas. Atualmente conta com cerca de 2 mil registros de sites da área da 
saúde reprodutiva, englobando temas como saúde materna (gestação, parto, puerpério), aborto, saúde perinatal, climatério, morbimortalidade relacionada à reprodução, contracepção/ planejamento familiar, sexualidade, DST/AIDS, violência sexual e doméstica, direitos reprodutivos, fertilidade e reprodução assistida, relações de gênero, ética e reprodução, maternidade/paternidade, aleitamento, transmissão vertical de doenças, gênero e direitos reprodutivos.

Na BVSR, assim como nas demais bibliotecas virtuais do PROSSIGA, o agrupamento dos registros é feito segundo categorias, como: bibliotecas, serviços de informação e centros de documentação, estatísticas, instituições de ensino e pesquisa, organização da sociedade civil, órgãos de política, coordenação e fomento, programas de pós-graduação, projetos e programas, eventos, especialistas e pesquisadores, bases de dados e bibliográficas, imagens, legislação e textos completos de livros, periódicos e outros.

Um serviço oferecido aos usuários é a edição do Boletim temático eletrônico trimestral, inserido na página principal da BVSR. Os boletins objetivam levantar os sites principais sobre temas escolhidos pela equipe, obedecendo critérios de oportunidade, relevância e demanda. Outros serviços oferecidos aos usuários são a possibilidade de sugerir sites e de cadastrarem seus currículos ou instituições. Os usuários podem também se cadastrar na Mala Direta e receber informações por email sobre as novidades da BVSR.

A equipe da BVSR é composta por profissionais docente-pesquisador, bibliotecários, alunos de pós-graduação e de graduação, estes últimos como bolsistas ou estagiários. A coordenação temática é realizada por docente do Departamento de Saúde Materno-Infantil da FSP/USP e a coordenação técnica é de responsabilidade de uma bibliotecária do quadro da Biblioteca da FSP/USP.

A função do docente é validar os registros inseridos, verificando se o tema tratado está adequado à área temática de saúde reprodutiva, orientar os bibliotecários nas respostas enviadas aos usuários, coordenar a definição dos 
temas e selecionar os registros para o Boletim eletrônico temático. Ele é o responsável pela qualidade do produto final (CHASTINET 1999).

A função do coordenador técnico é revisar os registros inseridos no âmbito técnico, ou seja, verificar se os resumos e descritores estão adequados, responder os emails recebidos, manter as estatísticas mensais e o cadastro de usuários* .

Aos bolsistas ou estagiários cabe a busca de sites, seleção e registro. A equipe atua sob a orientação da coordenação do PROSSIGA.

Dados do sistema do PROSSIGA apontam para um crescimento no uso da BVSR que teve 40\% a mais nas consultas de 1999 a 2001. No Quadro 1 são apresentados os movimentos de alguns serviços prestados pela BVSR aos usuários remotos.

Quadro 1- Comparação da quantificação dos serviços de comunicação com o usuário da BVSR, no período de $2^{\circ}$ semestre de 1999 ao $2^{\circ}$ semestre de 2000 e do $1^{\circ}$ semestre de 2001 ao $1^{\circ}$ semestre de 2002.

\begin{tabular}{|l|c|c|}
\hline Serviços & $\begin{array}{c}2^{\mathbf{o}} \text { sem. } 1999 \text { ao } 2^{\circ} \\
\text { sem. 2000 (18 meses) }\end{array}$ & $\begin{array}{c}1^{\circ} \text { sem. } 2001 \text { ao } 1^{\mathbf{o}} \\
\text { sem. 2002 (18 meses) }\end{array}$ \\
\hline Emails recebidos & 275 & 530 \\
\hline Emails enviados & 302 & 557 \\
\hline Cadastro na mala direta & 494 & 497 \\
\hline Comentário no livro de visitas & 14 & 10 \\
\hline Cadastro de pesquisadores & 8 & 20 \\
\hline Cadastro de entidades & 1 & 20626 \\
\hline Sites sugeridos & 12 & 1 \\
\hline Número de acesso à página & 10642 & 10 \\
\hline
\end{tabular}

Fonte: relatório enviado ao PROSSIGA em julho/02

* A BVSR conta com um cadastro de cerca de 1000 usuários, cujos registros foram fornecidos espontaneamente pelas pessoas que consultam o site, através do email para os contatos (bvsr@fsp.usp.br). 
Para o cadastro dos sites é utilizada uma metodologia desenvolvida pelo PROSSIGA e para indexação por assunto é utilizado o vocabulário controlado Descritores em Ciências da Saúde (DeCS), desenvolvido pela BIREME/OPAS.

Vários trabalhos de avaliação da BVSR foram apresentados em eventos da área, sendo a maioria discorrendo sobre o perfil dos usuários: FRANÇA JR e col. (1999a), FRANÇA JR e col. (2000) e NEVES (2001). Um dos primeiros trabalhos foi o de FRANÇA JR e col. (1999b) com a finalidade de divulgar a BVSR, contando os seus primeiros movimentos. Outro foi sobre as ferramentas de busca na Web ou metabuscadores, apresentado com o objetivo de informar a importância destas ferramentas na localização de sites para a BVSR (DELBÚCIO e FRANÇA JR 2000).

\subsection{Sobre as Categorias de Usuários}

Há vários anos os cientistas da informação preocupam-se em conhecer as necessidades de informação de comunidades específicas, como forma de adequar produtos e serviços destinados a essas comunidades. Com a inserção das novas tecnologias de informação, ocorreu uma mudança significativa tanto no tratamento da informação quanto no perfil dos usuários (HUMMELSHOJ 2000; JANES e col. 1999; WOLPERT 1998).

Verifica-se que as bibliotecas estão voltadas para a produção e organização de listas de sites e bases de dados com valor agregado para colocar à disposição dos usuários. Os usuários estão recebendo um atendimento de referência remoto. Conseqüentemente estão sendo criados modelos de avaliação dos serviços de referência na internet e instrumentos para verificar o perfil deste usuário, uma vez que eles estão longe da observação visual do profissional da informação (HUMMELSHOJ 2000). 
A Biblioteca Virtual, disponibilizada para acesso universal em 1999, teve sua utilização avaliada e alcançou seu objetivo inicial de divulgar as informações em saúde reprodutiva aos pesquisadores, profissionais, professores e estudantes interessados neste assunto (FRANÇA JR e col. 1999b).

Em outro estudo, FRANÇA JR e col. (1999a) verificaram que o maior número de usuários cadastrados de acordo com a instituição de vínculo era de universidades $(61,8 \%)$, composto, principalmente, por graduados $(39,1 \%)$, graduandos $(22,9 \%)$ e pós-graduandos $(38 \%)$.

Em pesquisa realizada um ano depois, FRANÇA JR e col. (2000) chegaram a dados semelhantes, ou seja, relativamente à instituição, os usuários estavam vinculados em sua maioria a universidades $(61,3 \%)$, sendo $39 \%$ graduados, $22,5 \%$ graduandos e $38,6 \%$ de pós-graduandos.

Estudo posterior (NEVES 2001) apontou o usuário da BVSR como predominantemente do sexo feminino (71\%), na faixa etária entre 21 e 40 anos (65\%), residentes principalmente em São Paulo (43\%) e Rio de Janeiro (11\%). As profissões ficaram assim distribuídas: professor $22 \%$, estudante $16 \%$, médico 11\%, bibliotecário/pesquisador e psicólogo 5\%. A freqüência de acesso foi maior no item uma vez por mês (41\%) e semanal (20\%) e a finalidade foi interesse acadêmico (43\%), seguido de interesse para o trabalho $(27 \%)$ e conhecimento pessoal $(22 \%)$.

O estudo de NEVES (2001) foi feito por meio de solicitação de preenchimento de um formulário na internet para os usuários cadastrados na mala direta da BVSR. A taxa de resposta foi considerada baixa, tendo sido feitas três convocações e que resultaram em respostas de $38 \%$ dos 874 usuários cadastrados. Destes, o maior grupo corresponde ao das mulheres em idade reprodutiva, residentes no Sudeste e com profissão e interesse acadêmico-universitários. 
Outro estudo, de CASTRO e col. (2001), fez uma análise do perfil dos usuários cadastrados nos serviços do PROSSIGA, em várias bibliotecas virtuais temáticas, sendo que na BVSR os usuários são principalmente estudantes $(34,5 \%)$, seguido dos profissionais $(34,2 \%)$, docentes $(18,2 \%)$ e pesquisadores $(10 \%)$, caracterizando, portanto, forte vínculo com a área acadêmica.

Quanto à origem geográfica dos usuários da BVSR, 94,9\% são do Brasil, sendo 59,7\% da região Sudeste e 24,4\% da região Nordeste (CASTRO e col. 2001).

Observa-se, também, que 61,8\% são da área das ciências da saúde, 15,2\% das ciências humanas e 13,2\% das ciências sociais. Outras áreas também aparecem, como: ciências exatas $(2,0 \%)$ e biológicas $(2,6 \%)$. Outra conclusão levantada no trabalho de CASTRO e col. (2001) é de que 92\% dos usuários se cadastram na primeira vez que acessam o serviço.

\section{OBJETIVOS}

Embora o usuário da BVSR já tenha quebrado as barreiras com o uso básico da tecnologia da computação, ele não atua criticando e dando sugestões. Pode-se observar que a comunicação do usuário dessa biblioteca com a equipe de trabalho é pequena, comparada com a do usuário remoto da Biblioteca da FSP/USP. Será que o sistema está oferecendo suficiente estímulo para isso?

No caso da BVSR qual seria a técnica de comunicação interativa mais adequada, tendo em vista seu pressuposto básico de atualização constante de informação na área específica para usuários especializados?

Considerando que a área da saúde reprodutiva é reconhecidamente composta, em grande parte, de pesquisadores e militantes, a indagação básica 
que se coloca é o porque a BVSR espontaneamente não se ter caracterizado como uma Biblioteca Virtual interativa?

Diante destas constatações e indagações, o presente trabalho propõe o seguinte objetivo principal:

Verificar como está se processando a comunicação entre a Biblioteca Virtual de Saúde Reprodutiva (BVSR) e o seu usuário. Tem-se observado que a mediação está sendo processada somente num sentido, da BVSR para o usuário, portanto, sem interação. Na medida em que o usuário da informação não está participando ativamente deste processo, a BVSR não recebe feedback, o que impede a equipe responsável de avaliar se as informações estão sendo adequadas ou não ao usuário e de alimentar mais dinamicamente o sistema. Este objetivo se desdobra em três específicos:

- Verificar como a BVSR está atendendo às necessidades e expectativas do usuário;

- Identificar as barreiras na comunicação entre os usuários e a equipe responsável da BVSR

- Identificar junto aos usuários da BVSR formas de comunicação interativa para ampliar o significado deste tipo de serviço.

\section{PROCEDIMENTOS METODOLÓGICOS}

\subsection{Natureza da Pesquisa}

O método adotado foi de natureza qualitativa com abordagem exploratória. Esta opção deveu-se ao fato de se considerar a pesquisa qualitativa mais adequada para avaliar a comunicação do usuário com a Biblioteca Virtual, ou seja, a partir da percepção dos usuários sobre o acesso à 
informação. É importante relacionar a opinião dos usuários, que são os incluídos nas tecnologias da informação e comunicação, com a teoria que está sendo desenvolvida sobre a cultura pós-moderna. Acredita-se que com a pesquisa qualitativa podem-se obter idéias e percepções que colaborem para complementar estudos qualitativos e explorar questões ocultas que não têm sido objeto de muito estudo (SHEARS 2002).

Segundo FONTES (2001) "os estudos de uso de redes têm sido dominados pelo enfoque quantitativo", mas, no entanto, as abordagens qualitativas são recomendadas para detectarem os significados atribuídos às redes eletrônicas pelas pessoas em ambiente variável, "questões que os simples estudos de freqüências de uso da rede não podem atender" (p.70).

Outro fator é que o estudo de bibliotecas está inserido na ciência da informação, abrangida pela área de ciências sociais aplicadas e, por tradição, os métodos qualitativos são amplamente aplicados na área das ciências humanas, obtendo bons resultados (DENZIN e LINCOLN 2000).

A área da saúde reprodutiva também utiliza bastante os métodos qualitativos para explorar novas questões, explicar dados quantitativos e gerar idéias para a melhora dos serviços e criação de novos programas. Vários exemplos da aplicação de métodos qualitativos em saúde reprodutiva são expostos na revista NETWORK EN ESPAÑOL (2002). Entretanto, os trabalhos realizados sobre a BVSR, apresentados anteriormente, foram de natureza quantitativa, motivo pelo qual a escolha de um método qualitativo poderia contribuir para uma avaliação mais abrangente desse serviço de informação.

Finalmente, considera-se o trabalho qualitativo mais desafiante, a partir do momento em que pretende entender os significados e intenções dos sujeitos da pesquisa. Considera-se que uma pesquisa mais aberta coloca os sujeitos mais à vontade, com mais liberdade de expressão, deixando fluir as opiniões. 


\subsection{Grupo Focal}

Grupo focal é uma técnica de pesquisa qualitativa composta por pequenos grupos de pessoas que se reúnem para discutir um tópico específico (CARLINI-COTRIM 1996). Normalmente participam de seis a dez pessoas, que não se conhecem, e discorrem sobre um tema, problema ou serviço definido. Participam, também, um moderador, que coloca as questões do roteiro, e um observador.

O grupo focal distingue-se de outras formas de grupo nos seguintes pontos (KERSLAKE e GOULDING 1996):

- Apresenta um moderador, facilitador, e não um entrevistador; o moderador pode participar da discussão, encorajar a equipe e não somente colocar as questões do roteiro.

- O assunto no grupo focal fica concentrado em determinado ponto ou atividade; no grupo de discussão, sem um moderador, o assunto tende a desviar-se.

- A interação do grupo também é um dado da pesquisa; nos grupos de discussão os dados de interação são geralmente desprezados, sendo aproveitadas somente as respostas das questões do roteiro.

KERSLAKE e GOULDING (1996) e KITZINGER (1995) observam que trabalhar com grupo focal não é fácil nem rápido, como muitos consideram à primeira vista. Trata-se de uma técnica bastante flexível e com graus variados de estrutura de discussão, exigindo do moderador alto nível de envolvimento com o assunto.

No que diz respeito a essa técnica KERSLAKE e GOULDING (1996)

informam ser uma técnica muito utilizada em bibliotecas e no campo da 
ciência da informação, principalmente para investigar as necessidades dos usuários.

LEITÃO (2003) recomenda a utilização desta técnica para avaliação dos serviços oferecidos por um sistema de bibliotecas, como suporte complementar às pesquisas quantitativas. Neste trabalho LEITÃO (2003) faz uma análise do grupo focal, levantando a literatura da área da ciência da informação que utilizou esta técnica. Foi considerada válida a aplicação desta técnica, cujo objetivo é ouvir o que os sujeitos têm a dizer, no caso os usuários de bibliotecas. Outras vantagens colocadas sobre a técnica são a viabilidade financeira, a facilidade de compreender os resultados e a possibilidade de transformação a partir dos resultados.

Apesar de originalmente usados para explorar estudos de comunicação, os grupos focais têm sido muito utilizados para estudos na área da saúde. KITZINGER (1995) explora esta temática, discorrendo sobre a aplicação desta técnica e concluindo que o grupo focal é bastante apropriado para estudos de atitudes e experiência, para examinar como os conhecimentos e idéias operam num dado contexto cultural e explorar como as opiniões são construídas.

CARLINI-COTRIM (1996) acrescenta que a escolha desta técnica tem como essência apoiar-se na interação entre seus participantes para a coleta dos dados, a partir de itens levantados pelo moderador, e não simplesmente um processo de pergunta e resposta. O propósito do grupo focal é gerar idéias, opiniões, atitudes e perspectivas.

O processo da discussão do grupo permite que as pessoas mudem de idéias a partir da opinião de outras, pois os pontos divergentes e convergentes são acordados no âmbito do "coletivo inteligente". LÉVY (2002) aborda este aspecto da inteligência coletiva como uma partilha das funções cognitivas, ou seja, a memória, o aprendizado, a percepção, comentado que "a partir do momento em que essas funções são aumentadas e transformadas por sistemas 
técnicos - algo de objetivo, externo ao organismo humano - elas poderão ser mais facilmente partilhadas" (p. 2).

Com a inserção das novas tecnologias nas atividades acadêmicocientíficas, especificamente da internet, houve a possibilidade dos pesquisadores se comunicarem por email, listas e grupos de discussão, substituindo parte das conversas presenciais. Assim, esses serviços da internet têm sido utilizados para coleta de dados para as pesquisas (CUENCA 2004).

A aplicação desta técnica pode se dar também através da internet, pois os estudos qualitativos priorizam as pesquisas executadas no "setting" natural, ou seja, no próprio ambiente dos sujeitos. O pesquisador se dirige ao ambiente dos usuários, que pode ser o microcomputador no seu escritório, por exemplo (GAISER 1997).

CHASE e ALVAREZ (2000) compararam o processo envolvido no modo eletrônico com o modo face-a-face de grupo focal e sua aplicação na área da ciência da informação. Verificaram que as diferenças mais significativas foram: os dados da análise são unidimensionais (somente texto), enquanto que no face-a-face são levadas em conta também as observações não-verbais; a coleta de dados é imediata, prescindindo da transcrição de fitas; a dependência da habilidade dos indivíduos em digitar textos com rapidez; as expressões ficam limitadas ao textual; e a discussão pode se perder com mais facilidade devido à participação não-presencial.

CHASE e ALVAREZ (2000) sugerem que esta técnica eletrônica pode ser empregada em estudos com usuários de bibliotecas virtuais e que as dinâmicas de comunicação eletrônica têm melhorado, levando a uma maior facilidade de aplicação desta técnica em ambiente eletrônico.

KRUEGER e CASEY (2000) também discorrem sobre a possibilidade da aplicação da técnica de grupo focal através de salas de bate-papo na 
internet, desde que as questões sejam focadas, os participantes se comuniquem sem inibições e o moderador consiga manter o controle e conduzir a discussão.

Outro trabalho que aborda o uso de grupo focal eletrônico (CROWLEY 1996) discorre sobre as vantagens da técnica, considerando-a bastante prática, barata e com resultados imediatos. Aponta as seguintes características e recomendações:

- O número de participantes ideal é de 8 pessoas, menor que num grupo focal tradicional, geralmente em torno de 12 pessoas.

- As reações emocionais não são possíveis de serem observadas num grupo focal eletrônico, a não ser que seja realizado com câmeras ou teleconferência.

- Limita os participantes por faixa etária ou por atividades profissionais, lembrando ser muito difícil trabalhar com um grupo de pessoas que não usam computador com regularidade

- O tempo limite do grupo não deve exceder 90 minutos, sendo que o grupo focal tradicional gira em torno de duas horas.

Outros trabalhos como o de O'CONNOR e MADGE (2003) concluíram que os silêncios ocorridos nas reuniões são difíceis de serem interpretados num grupo eletrônico, bem como há dificuldades na definição da ordem das colocações, que surgem de acordo com a velocidade em que as frases são digitadas e enviadas. $\mathrm{O}$ retorno nem sempre aparece na seqüência.

CLAPPER e MASSEY (1996) apontam a perda do fator expressões não-verbais como a maior desvantagem do uso de grupos focais eletrônicos. Sugerem estudos para verificar este fator. No entanto, o fato do moderador e dos participantes não estarem face-a-face, pode proporcionar um ambiente onde todos se sintam mais à vontade para colocar suas opiniões, uma vez que não se sentem intimidados pelas expressões, tom de voz, trajes e olhares das outras pessoas. Outra desvantagem pode estar contida no fato de alguns 
sujeitos se sentirem inseguros porque estão redigindo textos e as informações sendo registradas e avaliadas.

A presente pesquisa foi baseada em KRUEGER e CASEY (2000) que orientam sobre a escolha dos indivíduos para a formação dos grupos, como convidar as pessoas para participarem, como conduzir o grupo, como analisar os resultados das discussões e fornecendo outras informações de grande importância para um bom resultado na aplicação da técnica.

Para aplicação desta técnica do grupo focal optou-se pelo meio eletrônico, via internet, com os convites feitos por email, para um grupo selecionado de especialistas no assunto, mas dispersos geograficamente. Foi utilizado um software público para comunicação do grupo, que utilizou apenas a forma escrita (não havia som nem imagem).

\subsection{Os Sujeitos da Pesquisa}

Quanto à composição de grupos focais, alguns autores comentam vantagens e desvantagens em grupos homogêneos ou heterogêneos (CLAPPER e MASSEY 1996). Trabalhar com grupos homogêneos permite um aprofundamento do tema e evita-se uma dinâmica negativa, mais dispersa. Com grupos heterogêneos por sua vez, tem-se um levantamento de dados em campos desconhecidos, podendo fluir várias perspectivas e interesses.

Esta pesquisa levou em conta a homogeneidade no que diz respeito à categoria profissional, pois se propôs a trabalhar com um grupo de pesquisadores da área da saúde reprodutiva, e a heterogeneidade na origem geográfica. Como indicado por KRUEGER e CASEY (2000), a similaridade é a base para o recrutamento de pessoas para o grupo focal, devendo-se considerar também uma certa heterogeneidade do grupo quanto ao gênero e origem geográfica (GAISER 1997). 
Assim foram identificados 58 usuários da BVSR, constituídos por pesquisadores que participam de linhas de pesquisa na área de saúde reprodutiva em 20 diferentes instituições brasileiras (Anexo 4). Destes, a grande maioria já estava cadastrada na categoria "pesquisadores" da BVSR.

O primeiro contato com todos os pesquisadores foi realizado por telefone, seguido por email, com convite para a participação no grupo focal. Dos 58 pesquisadores contatados, 44 deram resposta ao convite. Destes, 17 confirmaram o interesse em participar, porém, apenas 14 pessoas participaram efetivamente. Os pesquisadores contatados puderam optar entre as datas definidas para as reuniões. O horário escolhido foi o da manhã, período com melhor conexão na internet.

Os pesquisadores que recusaram o convite antecipadamente justificaram-se com motivos diversos como férias, viagens a trabalho, ocupados em aulas, dificuldades no uso das salas de bate-papo etc.

Os três que haviam aceitado o convite desmarcaram a participação na manhã da reunião por motivos de força maior, impossibilidade de usar as salas de bate-papo no momento e viagem de última hora. Isto impossibilitou o agendamento com novos participantes. A literatura recomenda o recrutamento de $20 \%$ de pessoas além do necessário para a condução do grupo focal, para prevenir ausências inesperadas (CARLINI-COTRIM 1996), o que não ocorreu.

\subsection{Coleta de Dados}

Para o uso do grupo focal por meio eletrônico existem no mercado vários programas desenvolvidos, como Computer Mediated Dialogue (CMD) da School of Business da Clarkson University (CLAPPER e MASSEY 1996), o Internet Relay Chat (IRC), o Multiuser Dimensions (MUDs), Bulletin 
Boards, Web Forum, FirstClass, Conferencing (SoftArc) e Question Point, este último desenvolvido a partir de um chat para utilização nos serviços de referência da Biblioteca do Congresso dos Estados Unidos (MAXEYHARRIS 2003).

Outra ferramenta desenhada e desenvolvida para conduzir grupos focais eletrônicos é a Internet Focus Group (IntFG), criada por uma equipe da Universidade do Estado da Carolina do Norte (MONTOYA-WEISS e col. 1998).

Para o presente trabalho optou-se pelo uso do Internet Relay Chat por ser um programa gratuito, de manipulação simples e rápido na visualização das respostas. Esta ferramenta esteve disponível para uso no PROSSIGA, no serviço "Ponto de Encontro", para ser utilizado pelos usuários e equipes das bibliotecas virtuais, motivo pelo qual a primeira reunião foi realizada via PROSSIGA. Atualmente este serviço encontra-se em fase de reestruturação.

As demais reuniões do grupo focal foram realizadas com o mesmo programa, porém via Divisão de Engenharia Civil do Instituto de Pesquisas Tecnológicas (IPT), na Cidade Universitária, que disponibiliza serviço de salas de bate-papo de seu domínio.

A caracterização sócio-demográfica dos participantes foi obtida via telefone ou email. Essa identificação, como dados sobre o local de residência, gênero, atividades profissionais desenvolvidas e formação acadêmica, serviu para verificar a homogeneidade dos grupos quanto às atividades profissionais e área temática de interesse.

O contato com os 14 pesquisadores ocorreu em três momentos: a primeira reunião ocorreu no dia 3 de julho de 2003, com 7 sujeitos, e as outras duas nos dias 12 e 14 de julho de 2004 com 4 e 3 sujeitos, respectivamente. Todas tiveram, além da participação dos sujeitos, um moderador e um observador e se iniciaram às 10 horas da manhã. A distância de um ano entre 
uma reunião e as demais deveu-se aos problemas na utilização da sala de batepapo do PROSSIGA, que deixou de funcionar.

As opiniões dos participantes foram registradas em arquivos eletrônicos dos programas das salas de bate-papo e analisadas posteriormente pelo autor do presente trabalho que assumiu, também, o papel de moderador nas reuniões. Foi convidado e preparado um participante da equipe da BVSR para atuar como observador das discussões e registrar itens importantes levantados nas reuniões.

O papel do moderador no grupo focal eletrônico é bastante delicado, porque tem que manter o assunto foco na discussão e, ao mesmo tempo, dar liberdade para o grupo se expressar, sem usar a linguagem corporal, expressões ou tonalidades de voz.

Não foram utilizados os símbolos que expressam sentimentos na internet, conhecidos como Emoticons, pois a ferramenta utilizada não disponibilizava tal recurso. Apesar de ser a expressão que o participante quer transmitir e não a que foi observada, estes símbolos poderiam ajudar na análise das informações (GAISER 1997).

De acordo com o período limite sugerido por alguns autores (CHASE e ALVAREZ 2000; CROWLEY 1996), o tempo de duração de cada reunião foi por volta de 60 minutos.

\section{Questões aplicadas}

As questões são consideradas por KRUEGER e CASEY (2000) como "a alma do grupo focal". Esses autores indicam que deve haver de 5 a 6 questões abertas, evitando-se dicotomias e o uso do por quê. As questões devem ser claras, precisas, breves, apresentadas num contexto, indo do geral para o específico. Recomendam também que, antes de aplicá-las, seja feita 
uma acolhida de boas vindas, agradecendo a participação, e uma apresentação do moderador e do assunto a ser tratado, de forma resumida, pois nos contatos anteriores os participantes já devem ter claro o assunto a ser tratado.

As questões estabelecidas no roteiro passaram por seleção e avaliação no pré-teste realizado em junho de 2003 com um grupo composto por docentes, alunos de pós e de graduação da Faculdade de Saúde Pública.

Durante o contato com os participantes, algumas alterações ocorreram na ordem das perguntas, bem como a inclusão de outras questões à medida em que o moderador considerou adequado, porém sempre mantendo a consistência das mesmas. Os tópicos abordados foram:

1. Como pesquisador na área da saúde reprodutiva o que espera encontrar numa biblioteca virtual?

2. Normalmente quando entra numa biblioteca virtual ou sites, como você faz para iniciar uma pesquisa? Entra na caixa de busca? Procura pelos itens na página principal?

3. Qual sua opinião sobre os resultados da pesquisa encontrados na Biblioteca Virtual de Saúde Reprodutiva (BVSR)?

4. O que poderia ser modificado no site da BVSR para ajudar na pesquisa ou melhorá-la?

5. Como está hoje parece fácil entrar em contato com a equipe que trabalha na BVSR, seja por email, formulário ou telefone?

6. Sugira duas mudanças que poderiam ser feitas no site da BVSR para melhorar a comunicação. 


\subsection{Tratamento e Análise dos Dados}

Os dados registrados pela discussão nas salas de bate-papo foram lidos atenciosamente pelo moderador, que fez, primeiramente, uma análise ampla dos pontos abordados e, posteriormente, uma análise mais pontual, verificando as opiniões dos indivíduos e as mudanças de opiniões observadas durante a reunião.

Para o tratamento dos dados foram utilizadas técnicas de análise de conteúdo numa abordagem exploratória, baseadas em trabalhos de pesquisa qualitativa. Esta análise refere-se à "explicitação do sentido contido num documento e/ou o modo em que pode ser transformado com finalidade de oferecer um significado, tendo em conta palavras pré-escolhidas pelo locutor, freqüência de recorrência de certos termos, aparato e andamento do discurso" (TURATO 2003, p.440).

De acordo com KRUEGER e CASEY (2000) a análise dos resultados do grupo focal deve se pautar no propósito do estudo, isto é, o problema dirige a análise. A análise de um grupo focal é complexa porque, além de utilizar o dado puro, colocado individualmente, tem que comparar as respostas dos participantes. As palavras usadas nas respostas devem ser comparadas, considerando as relações internas. Os procedimentos da análise devem ser sistemáticos, seqüenciais, verificáveis e contínuos.

KRUEGER e CASEY (2000) sugerem três fatores a serem considerados na análise: 1) sistematização dos procedimentos através da documentação e entendimento das respostas; 2) os procedimentos devem ser verificáveis; e 3) a análise é feita concomitantemente com a coleta dos dados.

Com base nas recomendações de CARLINI-COTRIM (1996) para análise dos dados de grupo focal foram verificadas as respostas através das citações textuais dos participantes do grupo, que ilustram os principais achados da análise e também observada a repetição, a não repetição ou 
ausência das categorias explicativas das discussões e seus respectivos contextos.

\subsection{Termo de Consentimento Livre e Esclarecido}

GAISER (1997) destaca a importância das considerações éticas nas pesquisas em ambiente mediado por computador (ciberespaço). O ponto crítico é que, no passado, o pesquisador usava audiotape ou videotape e transcrevia os diálogos do grupo. Agora o pesquisador tem menor controle sobre os dados, uma entrevista eletrônica significa expor o texto discutido pelo grupo num ambiente que pode ser invadido por indivíduos não envolvidos na pesquisa. A fim de respeitar os direitos dos participantes o pesquisador precisa informá-los sobre os limites na segurança dos dados.

Para a elaboração da presente pesquisa em ambiente virtual, foram seguidas as normas para pesquisas envolvendo seres humanos, estabelecidas pela Resolução 196/96 do Conselho Nacional de Saúde (MINISTÉRIO DA SAÚDE 1996).

Assim, a participação dos usuários foi voluntária, com autorizações por email, que foram arquivadas. As informações pessoais, bem como os emails dos participantes, não serão divulgados. As respostas, após utilização no trabalho, foram arquivadas de posse da autora desta pesquisa e serão destruídas após cinco anos. Os participantes foram também informados de que não seriam considerados os erros de digitação.

\section{RESULTADOS E DISCUSSÃO}

Os resultados e discussão foram agrupados sob 3 critérios: enfoque na técnica do grupo focal via internet, por se tratar do uso de uma ferramenta 
ainda pouco explorada; nas respostas às questões focais, e nas discussões paralelas levantadas nos grupos focais.

\subsection{Sobre o Grupo Focal Via Internet}

A técnica utilizada apresentou pontos negativos e positivos na sua aplicação e na expectativa de resultados.

A maior dificuldade encontrada foi na localização de uma nova sala de bate-papo, após o fechamento da sala de bate-papo do PROSSIGA. Foi uma difícil procura pelas instituições da USP, o que tomou muito tempo. A localização dessa sala foi limitada também pela exigência de ser uma sala reservada, para evitar a entrada de pessoas desconhecidas e que, ao mesmo tempo, fosse de fácil utilização e possibilitasse a recuperação dos dados levantados. Foram testadas outras ferramentas como fóruns de discussão, mas o resultado não foi favorável para atender aos objetivos do presente trabalho.

Outra dificuldade foi a seleção dos participantes para as reuniões. Primeiramente seriam convidados a participar os usuários que se cadastrassem na Mala Direta da BVSR nos últimos dois meses procedentes à reunião. $\mathrm{O}$ cadastro era feito voluntariamente a partir da página inicial da BVSR. Com a suspensão deste serviço de Mala Direta em razão da mudança das instalações físicas e de informática do PROSSIGA do Rio de Janeiro para Brasília, em agosto de 2003, esta possibilidade deixou de existir.

Assim, optou-se pela seleção a partir das instituições da área da saúde reprodutiva no Brasil. Os sujeitos selecionados eram pesquisadores, na maioria docentes, muito ocupados com eventos, aulas, projetos, período de férias escolares e greve em grande parte das universidades brasileiras.

Os 14 participantes ficaram distribuídos em três grupos: 7 na primeira reunião, 4 na segunda e 3 na terceira. Este número de participantes nas duas 
últimas reuniões, embora abaixo do sugerido pelos estudiosos (7 a 10), pode ser considerado satisfatório, devido ao uso da tecnologia eletrônica. Um dos participantes da pesquisa observou que se o grupo fosse maior seria difícil de acompanhar:

“... Se fossem mais participantes, teria sido ainda mais complicado ler tudo e palpitar sobre tudo!"

$\mathrm{O}$ fato da pesquisa eletrônica ter sido realizada num instrumento desconhecido por muitos sujeitos também foi um dificultador. Em pesquisa feita em 2002 com docentes dos programas de pós-graduação da área de saúde pública no Brasil foi concluído que os recursos da internet, representados pelas listas de discussão, salas de bate-papo e teleconferências ainda são pouco utilizados pela comunidade acadêmica brasileira, assim como acontece em outros países. Não chegou a $10 \%$ a utilização de salas de bate-papo (Chat, ICQ) pela população estudada, sendo que o email é utilizado por $96,9 \%$ da mesma (CUENCA 2004).

Outros problemas operacionais também foram detectados. Assim, alguns participantes não conseguiam ler o que outros participantes escreviam, sendo que dois deles desistiram por este motivo, razão também pela qual nas duas últimas reuniões participaram efetivamente somente 4 e 3 pesquisadores, respectivamente. Alguns enfrentaram a lentidão do sistema. Um participante teve dificuldade de visualizar todas as respostas na seqüência:

"Parei de receber as mensagens. A última foi..."

"Infelizmente não consegui me comunicar com os colegas..."

"Pena a tecnologia ser ainda um pouco difícil"

O mesmo ocorreu com outro participante, que no meio da reunião informou:

“Minha página não está rolando...” 
Alguns participantes se surpreenderam com outros detalhes técnicos:

“...Desculpa gente, descobri que o Chat não aceita acento...”

“...a tela é muito estreita para ler as mensagens"

“...usem o tab para alcançar o botão de mensagem”

Quanto à digitação:

“...Gente. Estou horrorizada com meus erros de digitação”

“...Fique fria.. eu nem posso prestar atenção nisso, pois senão me imobilizo... Não sou digitadora...”

“...nos chats americanos é chic errar as digitações...casual”

Por outro lado, a técnica foi considerada positiva por vários participantes, que colocaram suas opiniões nas reuniões quando questionados sobre o grupo focal através de salas de bate-papo:

“...Espero que tenha sido útil para o propósito... Gostei muito de ter participado”.

“...Gostei de participar... Foi uma experiência ótima”

“...Eu gostei muito. Conheço grupos focais 'reais`e achei que esse, virtual, acaba se assemelhando bastante ao outro, desde que as pessoas se sintam à vontade para dar palpite na fala dos demais participantes, concordando ou discordando, ao invés de se restringirem a apenas responder o que é perguntado pelo moderador."

“Achei a experiência interessante. Às vezes um pouco lento o processo, mas de qualquer modo é um excelente meio de comunicação, os adolescentes que o digam, 'pendurados' que ficam por horas no MSN...” 
"Eu nunca havia participado, também gostei bastante, achei bastante válido. Eu nunca tive paciência para me comunicar no MSN, como muitos amigos meus, quem sabe agora eu não tente”.

"Nunca tinha tido esta experiência. Achei muito interessante. Pude entrar na página da BVSR antes para pensar algumas coisas. Foi legal. Pena a tecnologia ser ainda um pouco difícil"

"Eu nunca tive este tipo de experiência, mas achei legal. Acho que para fazer isto tem que ser algo bem pontual e curto, certo? E concordo (...), o nosso problema foi a tecnologia não ir tão rápido quanto o nosso pensamento e vontade de falar".;

"Achei legal mas é meio frustrante quando a velocidade não nos permite participar em tempo propriamente real".

Nestas três últimas colocações observa-se uma dificuldade de participação "em tempo propriamente real", pois como os textos vão aparecendo na seqüência em que são enviados, às vezes surgem dois ou três parágrafos ao mesmo tempo, dificultando a leitura e a concatenação das idéias.

Quem digita mais devagar envia a resposta bem depois dos demais, quando já estão sendo respondidas outras questões. Este fato foi observado nas três reuniões. Uma forma de resolver é solicitar que os participantes aguardem as respostas de todos para se colocarem novamente. Esta desvantagem foi citada no trabalho de O'CONNOR e MADGE (2003).

KRUEGER e CASEY (2000) recomendam uma pausa entre as questões no grupo focal face-a-face, o que deve ser feito também no grupo focal eletrônico. Para esta operacionalização poderiam ser colocados alguns caracteres ou as palavras "pausa" ou "aguarde" para que todos os participantes aguardassem a continuidade.

MUNRO e ZEIDMSAN-KARPINSKI (2003) fornecem orientações para uso de salas de bate-papo, constatando que são comuns erros de digitação 
e gramaticais, devido à rapidez com que são digitados os textos. Recomendam o uso de frases simples e curtas. Outros aspectos que influenciam a qualidade são a capacidade do computador e a velocidade de rede, que devem ser semelhantes entre os participantes do grupo, uma vez que as colocações precisam ser interpretadas em tempo real.

SMITH e col. (2000) tratam das dificuldades do uso das salas de batepapo, acrescentando que não há um contexto social para quem lê os resultados de uma reunião nestas salas. Assim, os registros devem ser lidos imediatamente após serem levantados para não se perder a cronologia do evento (histórico social). Eles propõem um programa de sala de bate-papo chamado "chats alinhados", para que os participantes insiram suas colocações próximas ao assunto tratado.

A grande facilidade dos grupos focais via internet é a possibilidade de reunir pessoas de vários lugares diferentes, acomodados em suas salas, escritórios, enfim, em ambientes de sua familiaridade, sem custo de locomoção.

\subsection{Respostas às Questões Focais}

As três reuniões foram iniciadas com as boas vindas, agradecimentos e apresentação da BVSR aos participantes. A seguir foram colocadas as questões.

Nesta parte do presente trabalho serão colocadas as respostas às questões a fim de categorizar as informações e facilitar as discussões. As respostas nem sempre apareceram na sequiência no texto, porque dependiam da agilidade da digitação para entrar na ordem das falas, mas foram reunidas abaixo de forma a facilitar a compreensão. Outro fator inconveniente foram 
algumas falas dispersas, que fugiam da pergunta em pauta. Diálogos paralelos também ocorreram, mas não atrapalharam no resultado final.

A primeira questão era mais ampla e versava sobre o que um pesquisador espera encontrar numa biblioteca virtual. Não foi conceituado nenhum termo a fim de deixar as respostas abertas. Com esta questão foi possível levantar as necessidades dos pesquisadores, atendidas ou não pela BVSR.

“Como pesquisador na área da saúde reprodutiva o que espera encontrar numa biblioteca virtual?"

Foram obtidas as respostas a seguir:

"Sempre tenho muitas expectativas... É claro que quero encontrar tudo que desejo e nem sempre é possível. No geral, porém, tenho conseguido ótimas informações no site”.

"A minha expectativa é que, por ser um site especializado em saúde reprodutiva, eu vá encontrar materiais que eu preciso no trabalho".

“...textos, pesquisas relacionadas à temática, espaço de encontro entre instituições e pessoas interessadas em determinado assunto"

“Artigos e publicações sobre o tema, dissertações e teses (...), lista de pesquisadores, centros e organizações que fazem pesquisa ou militam na área; cópias de artigos de jornais e revistas... (...) publicações (...) das Ciências Humanas (...) sob a forma de livros (...) dados estatísticos (...) com tabelas e gráficos ...”

“...pesquisa bibliográfica, contato com outros pesquisadores e localização de sites de interesse (...) dados estatísticos (...) indicações sobre sites onde estejam disponíveis (...) O acesso a papers, teses e dissertações ..." 
“...acesso remoto a bases de dados, catálogos de bibliotecas, textos completos de documentos e aquele atendimento atencioso..." “...link para trabalhos, (...) entrar em contato com o autor (...) um endereço para correspondência..."

“...sites de instituições de referência (...) divulgação de eventos, trabalhos sobre o tema e imagens para ilustrar as oficinas (...) emails para contato com os autores..."

“...fóruns permanentes...”

Quase todas essas expectativas apontadas são contempladas pela BVSR, apenas os seguintes itens propostos não estão disponíveis atualmente: espaço de encontro de pessoas e instituições, incluindo fóruns e links entre as divisões da BVSR, levantada implicitamente, quando solicitam "links para trabalhos (...) autor...”.

Verifica-se que a grande necessidade é encontrar material bibliográfico sobre o assunto procurado para ajudar nas pesquisas desenvolvidas, porém outros serviços são demandados, dados estatísticos, atendimento personalizado, diretório de pesquisadores e instituições, entre outros. Essas necessidades precisam ser mais estudadas, através de pesquisas periódicas com os usuários, a fim de oferecer serviços mais relevantes.

A biblioteca virtual, sendo um "agregado de informações", como a denomina BARRETO (1994), precisa oferecer serviços e divulgá-los à comunidade e, periodicamente, pesquisar as demandas para se adaptar às novas necessidades. É necessário rever a lógica da comunicação das bibliotecas virtuais, baseada na oferta de informações, sem considerar a demanda. É preciso saber que tipo de informação é importante para estes usuários. Por outro lado, sendo uma Biblioteca, é importante também manter a memória do que é produzido na área temática de sua responsabilidade. No 
caso de bibliotecas virtuais é preciso preservar a memória virtual encontrada na internet.

As respostas seguintes à referida questão revelam um assunto muito discutido atualmente - o tempo:

“...espero que ele seja rápido de se carregar, fácil de usar e que não seja muito poluído”.

"A minha expectativa é de que resolva o meu problema naquele momento, naquilo que estou procurando... de forma rápida e eficiente..."

"A agilidade do site é fundamental. Sites muito pesados são inviáveis na minha opinião”.

O fator tempo aparece nesta pesquisa, desde os contatos telefônicos e por email com os pesquisadores, que diziam estar sempre muito ocupados, até nos resultados das salas de bate-papo. Outras vezes, além das respostas a esta primeira questão, foram colocadas expressões referentes à falta de tempo, explicitamente ou implicitamente, mostrando uma das preocupações, por que não dizer, angústias do homem atual:

“Acho que as BVs e portais costumam buscar interação com o usuário, mas percebo que não tem ocorrido, talvez por falta de tempo das pessoas”.

“...quando pensamos em internet queremos tudo muito rápido...”

“O nosso problema foi a tecnologia não ir tão rápido quanto o nosso pensamento e vontade de falar”.

(Sobre boletins eletrônicos) "não consigo dar conta de ler todos os que recebo".

"Nunca tive paciência para me comunicar no MSN"

“contato por email com sites de instituições demora um pouco”. 


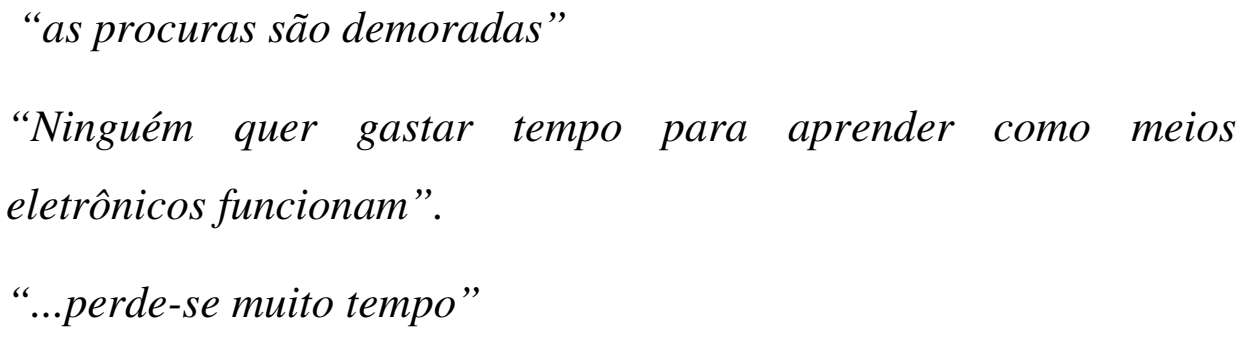

RIFKIN (2001) coloca as transformações que estão ocorrendo na economia ciberespacial emergente, que está deslocando todo o tempo livre remanescente dos indivíduos para a órbita comercial. Até mesmo as relações humanas estão se transformando em commodities, ou seja, sendo absorvidas pelo mercado. As máquinas de fax, email, telefones celulares, os mercados comerciais 24 horas, caixas eletrônicos permanentemente abertos atraem a atenção das pessoas, preenchendo as consciências, ocupando muitos dos pensamentos e tirando a maior parte do tempo de folga.

A economia baseada em rede aumenta a velocidade das conexões, tornando a vida mais conveniente, transformando muitas coisas em serviço, mas, por outro lado, as pessoas sentem-se como se não tivessem tempo para si mesmas, porque a enorme proliferação de serviços só aumenta a diversidade, o ritmo e o fluxo das atividades transformadas em commodities (RIFKIN 2001).

O excesso de informação disponível atualmente também aumenta a ansiedade nas pessoas, que precisam selecionar aquelas que interessam e processá-las, transformando-as em novas informações. Este procedimento faz parte da rotina dos pesquisadores e o problema transpareceu nos grupos focais.

A questão dois era mais objetiva e perguntava como fazem para pesquisar nos sites. Ela visava identificar dificuldades dos pesquisadores na hora de buscar as informações.

"Normalmente, quando entra numa biblioteca virtual ou sites, como você faz para iniciar uma pesquisa? Entra na caixa de busca? Procura pelos itens na página principal?" 
Através das respostas foi possível verificar segurança de alguns pesquisadores na utilização de sites, com detalhamento de procedimentos de acordo com as necessidades de pesquisa:

"Procurei pelos itens da homepage primeiro..."

"Sempre que entro numa página que tenha ferramenta de busca, às vezes tento até usar operador booleano, mas acho que não sou a regra”.

"Atualmente faço as pesquisas pela caixa de termos de busca. Tem dado muito certo".

“Entrei pela caixa de busca. Procurei por palavras. Depois usei os itens da homepage”.

"Eu costumo usar a caixa de busca (simples e uma olhada na busca avançada para ver os recursos)... após olhar os itens/categorias para saber que tipo de informação o site contém, mas eu gostei de ter acesso à busca por termos”.

"Depende do tipo de site e dos propósitos de busca. Por exemplo, uso muito a base Medline para identificação de artigos na área de saúde. Nesse caso a entrada é direta para o sistema de busca através de descritores. Costumo usar a ferramenta Google para localização de textos em pdf que não estão disponíveis no portal de periódicos da CAPES.”

"Depende do que estou procurando. Se é um assunto específico, tento achar a caixa de busca e coloco geralmente uma única palavra do termo que procuro. Dependendo do resultado, vou refinando a busca. Se procuro um serviço específico, verifico nas legendas do site quais são os oferecidos e entro no que me parece mais viável..." 
"Eu costumo navegar primeiro pelas opções que o site oferece no menu, se não encontrar o que estou procurando uso a busca disponível ou o Google para a busca dentro deste site especificamente".

Através de palavras e expressões colocadas nas respostas verificou-se a familiaridade dos sujeitos com a internet e seus instrumentos: "operador booleano", "caixa de busca", "homepage", "ferramenta Google", "descritores" entre outros. Não foram colocadas dificuldades dos pesquisadores nessas respostas.

Os sujeitos dessa pesquisa fazem parte da elite, incluída no mundo digital, inserida no mercado de trabalho competitivo. Trata-se de um coletivo politizado e dinâmico, haja vista a posição progressista das participações brasileiras em eventos internacionais desta área, como exposto no capítulo 3.1. Este coletivo está envolvido com questões sociais e educacionais e tem competência, conhecimentos e saber para poder ajudar a promover a inteligência coletiva. É uma boa oportunidade pensar em trabalhar com este grupo de especialistas para levar conhecimento às camadas mais desfavorecidas e tornar real o que CASTELLS (1999) disse sobre a expansão da comunicação mediada por computador, que se fará em ondas, partindo das elites, principalmente via sistema educacional.

A terceira questão era mais específica e dizia respeito aos resultados de busca encontrados na BVSR. Com ela pretendia-se verificar empecilhos, problemas para efetivação da comunicação da BV com seu usuário. Também foi possível verificar se os pesquisadores em questão utilizaram a BVSR anteriormente ou para esta pesquisa, como foi solicitado por email.

"Qual sua opinião sobre os resultados da pesquisa, encontrados na Biblioteca Virtual de Saúde Reprodutiva (BVSR)?” 
Um pesquisador disse não poder responder a esta questão por nunca ter acessado a BVSR, um segundo não respondeu, enquanto outro disse que não usa a BVSR para ver resultados de pesquisas:

"costumo não me restringir a apenas recorrer a $B V$, mas sempre começo por ela...”

"Quando usei, gostei do que achei..."

"O formato dos resultados é satisfatório, os links são bons facilitadores"

"Fiz uma busca ontem sobre gravidez na adolescência, para as alunas de graduação, e tive 120 registros como resultado. Foi excelente”.

"Mas aqui na sala de alunos, ouvi recentemente alguém que se queixava nunca encontrar assuntos que buscava - sobre psicologia administrativa”

Observa-se que o assunto colocado, "psicologia administrativa", não está contemplado no repertório de assuntos da BVSR. Porém, os usuários nem sempre buscam um assunto "fechado" dentro de uma área temática. Verificase que um assunto pode se desdobrar para temas bem dispersos. Daí a necessidade de uma biblioteca virtual ter ligações com outras de outros temas. Esta parece ser também uma demanda dos usuários, que precisa ser verificada através de novos estudos.

Um pesquisador se posicionou dizendo:

“...Costumo preferir artigos publicados que já passaram por revisão de pares e nesse caso uso as bases tradicionais (Bireme, PubMed etc)"

Este pesquisador depois completou que "uma das principais dificuldades de quem quer fazer pesquisa bibliográfica na internet é saber que 
fontes são confiáveis" e acrescentou uma sugestão dizendo que a "viagem" num site precisa ter volta, pois "as possibilidades de itinerários - links que se abrem sucessivamente - são quase infinitas".

Nesta colocação evidencia-se a exaustividade de informação apresentada com as novas tecnologias e a angústia do pesquisador que, diante de tantas fontes de informação oferecidas, elege somente algumas para se apoiar, normalmente aquelas vinculadas às instituições de sua confiança.

A confiabilidade de um site é percebida pelo usuário através da autoridade da fonte, ou seja, da instituição que o mantém e, para facilitar o entendimento da forma como as informações estão estruturadas, ele deve ter um projeto de arquitetura que vise permitir ao usuário chegar às informações intuitivamente (FURQUIM 2004).

Os critérios de qualidade a serem atribuídos a um site são similares aos que auxiliam na avaliação da informação impressa, ou seja: credibilidade, conteúdo, apresentação, links, design, privacidade e proteção dos dados, política editorial, interatividade e anúncios. Acrescente-se a esses a disponibilidade de mecanismo de busca, legenda com a atualização do site e dados de direito autoral (LOPES 2004).

EYSENBACH e KÖHLER (2002) apresentaram como resultados que os usuários procuram e avaliam informações pela credibilidade da fonte, pelo design profissional, pelo toque oficial ou científico, língua e facilidade de uso. Outra conclusão a que chegaram foi que pouquíssimos usuários anotaram ou se lembravam dos sites que utilizaram para recuperação de informações, o que pode também ocorrer com os usuários da BVSR, que entram uma vez e depois esquecem o endereço para retornarem.

Na primeira reunião houve dispersão na resposta da terceira questão, com a colocação de sugestões. Nas demais reuniões ocorreram fatos semelhantes: um dos pesquisadores retomou a resposta da primeira questão e 
não respondeu a esta terceira, não sendo possível concluir se por distração ou propositalmente. Algo parecido ocorreu com um pesquisador na terceira reunião, que desviou o assunto interagindo com outro participante sobre os pesquisadores enviarem seus trabalhos para divulgação na BVSR.

Um pesquisador colocou um grande problema enfrentado hoje pela BVSR, que é a questão da atualização. A desatualização faz com que diminua a credibilidade. Atualmente a BVSR conta com uma equipe pequena que trabalha pouco tempo na sua atualização e manutenção, mas é necessário implementar ações para minimizar problema. Mais colocações a respeito:

"Há vários links not found. Mas isso é inevitável em quase todos os sites"

"Algumas vezes os links não funcionam. Quando isso acontece é um problema"

“...o que tem publicado é infinitamente menor do que eu conheço que existe”. O mesmo pesquisador foi questionado se ele teria percebido a desatualização da BV, o que foi confirmado por ele:

“Sim, é o que eu percebo. É que talvez as produções relativas à saúde reprodutiva sejam mais amplas. Nem todas as organizações não governamentais estão listadas e contribuem para a BV. Outra coisa o NEPO da UNICAMP também tem produções nessa área e não aparece”.

$\mathrm{Na}$ colocação do próximo pesquisador ficou clara a necessidade da integração deste site a outros como tentativa de evitar a desatualização:

“...já usei várias vezes a Biblioteca Virtual e senti que o resultado fica limitado aos conteúdos dos sites, que são interessantes, mas informações de sites mudam constantemente. Acredito que a Biblioteca Virtual pudesse ter também, no mesmo resultado de 
busca, outras fontes (bases de dados, portal CAPES, SciELO, portal de teses, catálogos de bibliotecas etc)".

A quarta questão pedia uma sugestão de modificação no site a fim de facilitar a pesquisa ou melhorá-la. Esta questão não foi colocada na terceira reunião, devido à dispersão ocorrida na ocasião e porque nas outras reuniões esta questão ficou muito parecida com a sexta, que pedia duas sugestões para melhorar a comunicação.

“O que poderia ser modificado no site da BVSR para ajudar na pesquisa ou melhorá-la?"

Um pesquisador disse que falta maior divulgação das fontes seguras de informação, como a BVSR. Outro pesquisador sugeriu que se colocassem listas de fontes confiáveis organizadas por segmentos de usuários, o que foi aprovado por outro participante.

A resposta de outro pesquisador foi:

“Talvez vocês pudessem organizar as várias temáticas desenvolvidas pela Biblioteca em 4 ou 5 grandes blocos, por exemplo, Prevenção DST/Aids; Maternidade/Paternidade; eqüidade de gênero... Acredito que, em alguns casos, isso poderia facilitar a busca”. Cabe lembrar que atualmente a BVSR está organizada em grandes blocos por tipo de site, como imagens, pesquisadores, bases de dados etc, e não por assunto como sugerido.

Quanto a esta sugestão já existe a experiência no site da Biblioteca Virtual de Saúde, módulo Saúde Pública (BVS-SP)* , organizado em 24 grupos temáticos, que ficam disponíveis no site para buscas. Esta sugestão pode ser viabilizada na BVSR, com a criação de uma nova página principal com a divisão por grandes assuntos. Pesquisas deverão ser feitas para atualização do

\footnotetext{
* A BVS-SP é uma biblioteca virtual, resultado do trabalho cooperativo das instituições: Ministério da Saúde, BIREME/OPAS, Faculdade de Saúde Pública da USP, Escola Nacional de Saúde Pública/FIOCRUZ, CNPq e ABRASCO. Situa-se no endereço eletrônico: www.saudepublica.bvs.br.
} 
âmbito da área de saúde reprodutiva, com inclusão de novos temas e redirecionamento de outros.

A quinta questão referia-se à comunicação direta dos usuários com a equipe, seja por email, telefone, sala de bate-papo, entre outros.

"Como está hoje parece fácil entrar em contato com a equipe que trabalha na BVSR, seja por email, formulário ou telefone?"

Um pesquisador achou interessante manter mala direta de pesquisadores e organizar conversas por salas de bate-papo, mas não disse se considerava fácil a comunicação tal como está na BVSR. Outro pesquisador concordou com este e disse:

"Eu acho fundamental haver um espaço para o usuário 'se comunicar' com o site. O CNPq por exemplo, responde com bastante eficiência quando se faz consultas via página de atendimento. Talvez fosse interessante a BVSR promover chats de vez em quando, sobre temas específicos, com públicos específicos”.

FONTES (2001) coloca exemplos de situações em que as salas de batepapo são utilizadas para os serviços de referência aos usuários, principalmente no exterior. No Brasil, este uso parece ainda não estar disseminado, sendo até mesmo visto com certa reserva. O trabalho de MAXEY-HARRIS (2003) expõe o serviço de referência remoto através de um software desenvolvido para este fim nos serviços de referência da Biblioteca do Congresso nos Estados Unidos.

ARELLANO (2001) aponta as salas de bate-papo como uma opção para serviços de referência virtual em bibliotecas, porém observa que são pouco usadas devido às complicações apresentadas na configuração e funcionamento. 
A experiência da BVSR em atendimento direto ao usuário é através do uso do email. Porém, como colocado anteriormente, são poucos os emails recebidos com solicitações de usuários.

Como exposto anteriormente, o serviço de referência tem sofrido o impacto da internet, com mudanças na interação dos mediadores da informação e os seus usuários. Neste novo ambiente é possível "explorar o uso de recursos eletrônicos como o correio eletrônico, a videoconferência ou o bate-papo eletrônico, além dos tutoriais textuais e multimídia, utilizando, de maneira eficiente, as novas mídias digitais" (SILVA 2001; p. 99).

Com uma sala de bate-papo e uma equipe disponível em horários determinados para atender aos usuários, talvez aumentasse o número de consultas, porque os usuários não teriam que esperar pelas respostas, como ocorre com os emails. Nas pesquisas aplicadas neste trabalho verificou-se que muitas experiências negativas dos participantes com a internet foram os emails não respondidos.

Outras respostas sobre a comunicação com a equipe:

"Sempre foi fácil para mim, não tenho encontrado problemas, mas não tenho usado todos os recursos"

"Nunca precisei entrar em contato com a equipe. Mas também não usei todos os recursos"

"Acho que a correspondência por email facilita bastante, mas a efetividade da comunicação vai depender da freqüência com que as mensagens são verificadas"

"Sobre o contato com a BVSR, eu nunca tentei"

Dois pesquisadores observaram que em sites de instituições, às vezes, as respostas às questões não são imediatas, costumam demorar. Consideram o contato por telefone mais eficiente. Outro pesquisador opinou: 
"A comunicação entre o usuário e a biblioteca virtual é o grande diferencial para que ela tenha qualidade. Como numa biblioteca tradicional, a possibilidade de conversar com alguém que te dê respostas que não encontrou no site é fundamental. Personaliza o atendimento e o usuário volta".

Houve uma sugestão para a localização dos contatos no site:

"O espaço para comunicação poderia ser localizado no topo da página, assim, teria mais visibilidade. Vocês desenvolvem algum tipo de boletim eletrônico? Acho este ...".

Desta forma várias sugestões emergiram desta questão, destacando-se a importância da resposta imediata através do email.

A sexta questão pedia duas sugestões de mudança para melhorar a comunicação na BVSR.

"Sugira duas mudanças que poderiam ser feitas no site da BVSR para melhorar a comunicação"

As respostas, levantadas a partir dos discursos abaixo, foram: fazer um boletim eletrônico, divulgar a BVSR para os pesquisadores, modificar o site, canalizando-o para públicos específicos; organizar discussões, possibilitar a inclusão de trabalhos de pesquisadores no site, integrar-se a outras bases de dados, atualizar informações no site. Uma colocação foi:

"mudança no visual, tornando-o mais moderno e atraente, com bolinhas piscando, chamando a atenção para as novidades, enfatizando temas polêmicos e atuais".

Um participante concordou e dois outros discordaram por considerarem bom o visual atual por apresentar

"uma linguagem simples, como de revistas, as poucas imagens são pertinentes e não poluem a página (...) ser simples e direto”. 
Segundo Rosa Maria Villares de Souza Berto*, especialista em Marketing e Informação Tecnológica, o aspecto visual de um portal deve ser pensado em função do público-alvo, sendo que segmentos específicos, como adolescentes, terceira-idade; podem requerer alguma criatividade e ousadia na organização visual das páginas. Esta pesquisadora também informou que a tendência visual está em páginas mais "limpas" e focadas e que os portais devem garantir aos usuários interatividade e linguagem adequada.

Outra sugestão foi para que o site permita a navegação, mas não perca de vista a página principal.

Foi sugerido também:

“Inclusão de bibliografias no final de cada tema (...) sugestão de 3 autores ou assuntos afins para cada artigo, com links”.

Um outro participante endossou a sugestão colocando que alguém da área deveria definir as "bibliografias obrigatórias".

Outras sugestões:

“Textos completos de artigos, a exemplo do Scielo...".

“Aumentar o número de textos completos".

"Freqüência na verificação e respostas das mensagens por email”

“...Vocês desenvolvem algum tipo de boletim eletrônico? Acho que este instrumento é bastante positivo para melhorar a divulgação $e$ aumentar as possibilidades de comunicação do site”.

“Os boletins são uma forma interessante de divulgar os artigos, grupos que estão trabalhando com o tema, sites de interesse etc. Isto porque o eixo é o tema do boletim, o que ajuda a focar um assunto”.

\footnotetext{
* Informação obtida em entrevista por Chat, disponível em URL:http://www.ipt.br/tecnologia/chat [2004 jul 13]
} 
No meio do bate-papo surgiu um complemento a esta sugestão:

"Às vezes, acontecem fatos relevantes em relação à saúde reprodutiva. Isso pode ser um elemento que desencadeasse uma discussão ou um boletim"

Os boletins eletrônicos foram considerados importantes pelos participantes da pesquisa, principalmente como forma de divulgação da BVSR. Isto realmente ocorre quando são lançados números novos do boletim e enviados emails para os participantes da mala direta. Alguns cuidados devem ser tomados: quanto à periodicidade e tamanho, para não incomodar as pessoas, e quanto à estética e conteúdo dos boletins, isto é, ser atraentes e informar sobre temas de interesse aos usuários.

Outras sugestões apresentadas:

"Continuar com a divulgação de pesquisadores, instituições de pesquisa, notícia, eventos na área, coisa que não é bem divulgada pelos meios de comunicação. São informações preciosas que, a meu ver, deveriam permanecer, pois são de grande utilidade".

"outros tipos de informação também como estatísticas ou imagens, ou mesmo outras ONGs que trabalham na mesma área para um contato..."

“...colocar na primeira página um assunto do mês, chamando a atenção para os sites novos referentes ao tema escolhido. Poderíamos escolher o assunto de acordo com as datas internacionais (OMS etc)"

Normalmente na BVSR, bem como em outras bibliotecas virtuais, procura-se dar destaques às informações que estão sendo divulgadas na mídia naquela ocasião, seja televisão, jornais etc. Será que não há uma saturação desta informação? Questiona-se se as informações oferecidas nas bibliotecas virtuais têm que estar desprendidas da repetição com a mídia para evitar a 
comunicação "tautológica", que é uma junção de autismo com repetição (SFEZ 1996a). Adotando a sugestão deste autor, é preciso fornecer bases para permitir a interpretação da informação e promover o distanciamento entre o emissor e o receptor na avaliação da mensagem. Uma sugestão seria, a partir dos assuntos emergentes e em destaque na mídia, abrir um espaço para discussão, procurando colocar informações opostas às normalmente divulgadas para provocar uma reação do público.

Outra colocação foi disponibilizar um item com sugestões de assuntos e não somente com sugestões de sites, como existe atualmente. Esta sugestão parece ser viável. Outros participantes acrescentaram que isto criaria um

"clima de debate, atualidade (...) a possibilidade de participação é sempre interessante..."

“Acho que quanto mais 'vivo' o site estiver, provocativo, atual... mais ele se torna interessante e dá mais vontade de consultar".

Novamente a questão da divulgação é colocada, acrescida da sugestão da BVSR se dirigir a públicos específicos:

“...acho que o primeiro passo deveria ser a divulgação da BVSR entre os pesquisadores (...) também para públicos mais específicos, como prefeituras, por exemplo"

“...1) modificar o layout dirigindo informações a públicos específicos;2) organizar discussões sobre temas relevantes, tanto no diz respeito a questões emergentes/polêmicas e resultados inovadores de pesquisa, quanto no debate de temas relacionados às políticas públicas, por exemplo, normas técnicas, projetos de lei etc."

A questão das parcerias atuando nas bibliotecas virtuais é levantada na seguinte fala: 
“...uma proposta possível é disponibilizar ao pesquisador de saúde reprodutiva a oportunidade de incluir seu trabalho na base, preenchendo um formulário eletrônico que deve receber validação da equipe para que a base não fique desfocada. (...) É possível a comunicação com outras bases, como aquelas produzidas pelo NEPO UNICAMP?"

“...acho que o mais importante é trabalhar pela atualização do banco de dados, mas acho desnecessário duplicar informação. Se um artigo por exemplo já está disponível em outra base vamos manter o link...”

O trabalho com parcerias é bastante importante nas bibliotecas virtuais. Trabalhando com um grupo de instituições parceiras as bibliotecas virtuais ficam mais ricas em informação, há economia de recursos e a credibilidade aumenta. O PROSSIGA tinha a intenção de incrementar este sistemas nos seus objetivos.

Uma sugestão que apareceu de forma implícita nas respostas foi a integração dos itens do site, como links entre as bases de dados de textos completos, boletins etc. A BVSR foi desenhada para ser um diretório de links, com alguns serviços acoplados para interação com os usuários. Sendo assim, esta sugestão não poderá ser acatada se continuar com o atual programa utilizado. Outras bibliotecas virtuais já trabalham com uma tecnologia diferente, como as bibliotecas virtuais da BIREME, que utilizam metodologia comum e compatível para fazer as integrações de bases de dados, diretório de links, periódicos eletrônicos, diretórios de pesquisadores etc. Dessa forma, é possível utilizar um programa de metabusca que pesquisa simultaneamente em diferentes bases de dados (BIREME/OPS 1998). A viabilidade dessa sugestão 
depende do novo software a ser utilizado pela BVSR, que está atualmente em estudo pelo IBICT*

Várias colocações feitas provam que a BVSR não está sendo utilizada em sua totalidade, pois algumas sugestões colocadas já existem e alguns participantes informaram que não usam muito e nem conhecem bem os recursos oferecidos. A pouca utilização por parte dos pesquisadores foi um fator negativo na participação nas reuniões e demonstra a necessidade de maior divulgação dos produtos e serviços da BVSR, bem como deve ser pensada uma capacitação, provavelmente à distância, para uma melhor utilização.

\subsection{Discussões Paralelas nas Reuniões}

Além das respostas às questões centrais foi possível levantar as discussões paralelas e as provocadas por novas questões e comentários colocados durante as reuniões, que provocaram maior interação. Num grupo focal a interação entre os participantes deve ser encorajada para permitir a construção das opiniões. São comuns, também, as perguntas de improviso, desde que o moderador consiga manter o foco no assunto determinado e que a dispersão não se torne incontrolável.

Os nomes dos sujeitos das falas apresentadas a seguir são fictícios para preservação de suas identidades.

\section{Primeira reunião}

Foi proposta uma questão de improviso pelo moderador, incitando a discussão "O problema maior é este: como estimular os usuários para que

\footnotetext{
* Segundo informações da Dra. Bianca Amaro, coordenadora nacional do programa PROSSIGA/IBICT em 14/05/2004
} 
enviem sugestões para a BV, lembrando que estes usuários são virtuais?". Como respostas um participante citou um exemplo, dizendo que recebeu uma notícia através de uma lista de discussão, fato que o motivou a consultar o site. Outro participante colocou que o estímulo "vai depender de maior agilidade da página e maior dinamismo também", bem como da "divulgação da BVSR nos sites das ONGs e instituições, para que ela possa ser mais consultada e conhecida". Outra colocação diz que a interação ajudaria o usuário, que poderia contar com a colaboração de um grupo, e "o pessoal da BV que pode investir nos temas mais procurados". Outra sugestão: colocar caixas de diálogos ou enquetes eletrônicas com o usuário, solicitando sugestões e cadastros.

Pensando que estas opções já existem no site da BVSR, foi apresentada uma consideração pelo moderador: "Fico pensando se as pessoas já entendem a internet como uma forma de se manifestarem, opinarem, aprenderem, participarem". A partir disso foram colocadas idéias interessantes, como:

"talvez estes itens (comunicação) estejam 'apagados' no site" "às vezes falta tempo, mas é também falha de muitos sites que apenas informam e não dão a oportunidade de expressão", "falta um marketing bem articulado", "acho que os meios eletrônicos têm muita dificuldade de uso, e ninguém quer gastar tempo para aprender como meios eletrônicos complexos funcionam"

"Uma grande parte das pessoas no interior dos estados não possuem computadores e não sabem ao menos como entrar na internet, estamos falando de Brasil? País das diferenças"

Uma interessante colocação feita por uma pesquisadora possibilitou retomar o tema das mudanças culturais pelas quais passa a sociedade. 
“Acho que é uma fase de transição... a cultura está mudando... é preciso dar um tempo para isso..."

A comunicação está caminhando da cultura de massas (comunicação "um-todos" de LEVY, 1996) para o surgimento da cultura da virtualidade real (CASTELLS 1999) ou, na opinião de LEVY, 1993, para o pólo informáticomediático (comunicação “todos-todos”), ou ainda, para a comunicação em rede ou eletrônica (RODRIGUES 1994).

$\mathrm{Na}$ cultura de massa as mentes absorvem as mensagens de forma associativa/lírica, sem envolver esforço psicológico ou raciocínio de análise, sem feedback. A nova fase caracteriza-se pela possibilidade de compartilhamento dos hipertextos entre os atores da comunicação, o que promoverá novas formas de inteligência coletiva mais flexíveis e democráticas, fundadas na reciprocidade. Com a internet surgiu um sistema de comunicação interativo, resgatando a mentalidade da tipografia e a recuperação do discurso racional.

A comunicação informático-mediática também está nas mãos de grandes provedores que já dominavam a comunicação na mídia, como Globo, UOL, AOL etc. É preciso ter consciência de que os provedores sem fins lucrativos, como os das universidades, têm a responsabilidade de promover com qualidade esta comunicação "todos-todos" e com serviços expandidos para o público heterogêneo da internet. Caso contrário, a interação comunicacional das novas gerações ficará no âmbito de escolher quem ganhará o "Big Brother" ou quem será a "Princesinha do Verão" * e não em discussões e avaliações de serviços e informações. É preciso promover a construção de coletivos inteligentes.

\footnotetext{
* Big Brother é um programa em que várias pessoas ficam numa casa sendo constantemente filmados e os telespectadores votam para indicar os participantes que ficam ou saem da casa, através da Internet ou telefone. Princesinha do Verão fez parte de um quadro do programa de televisão chamado "Fantástico"em que são escolhidas mulheres pelo público através de votação pela Internet ou telefone.
} 
As bibliotecas virtuais devem atuar na preservação e divulgação da informação para beneficiar o conhecimento na cibercultura. Este segmento, segundo MONTEIRO (2004), é o que mais se beneficiará com o mundo virtual, dada a disponibilidade e facilidade de acesso.

A sociedade deve ser preparada para ter uma visão crítica, fazer uma desconstrução, buscando significados escondidos ou subentendidos numa informação, seja textual, imagem, sonora; mostrando contradições internas e falando dos sentidos contra-intencionados (TURATO 2003). Todas as pessoas têm competências para compartilhar e desenvolver o espaço do saber e a inteligência coletiva (LÉVY 2000).

Para FASSLER (1998) o abismo digital que se formou na sociedade deve-se ao fato das tecnologias terem se desenvolvido paralelamente às ciências sociais e à teoria da comunicação. A tecnologia não interagiu com as humanidades durante muito tempo. Dessa forma criou-se um coletivo pensante, envolvido com questões educacionais e sociais, desvinculado do outro coletivo pensante envolvido com as tecnologias nas ciências exatas. No encontro destas duas categorias, desencadeado pela internet, a população tomou contato com as tecnologias sem terem desenvolvido senso crítico a respeito, as idéias não foram trabalhadas, não houve tempo para discussão se esta ferramenta era boa ou não, a velocidade se sobrepôs ao raciocínio e uma elite mergulhou de cabeça no mundo virtual, sem ter preparado outras classes sociais.

O resultado disso é a exaustividade do oferecimento de informações e o pouco tempo e escassez de formação cognitiva para aflorar o conhecimento real. Para LÉVY (2000) a formação cognitiva é a junção da competência, desenvolvida pelas relações com as coisas; o conhecimento, desenvolvido das relações com os signos e informações, e o saber, desenvolvido através das relações com os outros. 
A sociedade está inserida na cultura de massas, que constitui um empecilho à passagem para a cultura interativa. A massificação da cultura separa os bens culturais pelo seu suposto valor de mercado, cria a ilusão de que todos têm acesso aos mesmos bens, inventa um espectador "médio" através do fornecimento de informações já conhecidas para não perturbá-lo e define a cultura como lazer e entretenimento (CHAUI 2001).

Uma colocação interessante de um participante das reuniões ressalta o costume trazido da comunicação "um-todos" da mídia quando diz: "Talvez não estejamos acostumados a usar a internet para interagir com outras pessoas ou debater idéias". A internet estará sendo usada somente como a comunicação "um-um" (email) ou um-todos ("websites")? Será que o coletivo conseguirá se desprender desta cultura que o categoriza pelo poder econômico, o informa de acordo com interesses também econômicos, dispersa a atenção e diminui a capacidade de pensar, infantiliza e o torna passivo?

Nas respostas às questões da primeira reunião observa-se várias vezes a interação entre os participantes, ora concordando, ora discordando, ora complementando. Este é um pequeno exemplo da comunicação "todos-todos". Cláudio, Malu e Cida são sujeitos dessa reunião:

“Concordo com o Cláudio”

"Eu idem a Cida”

“Cláudio, que problemão!”

"Concordo inteiramente com a Malu”

“Eu gosto da idéia da Malu também”

"A Cida apresenta uma sugestão neste sentido"

“A sugestão do Claúdio nem sempre funciona”

"Malu, nos chats americanos é..." 
Também na primeira reunião a participante Kátia colocou um comentário sobre uma questão polêmica, o aborto, que não se desdobrou entre os outros participantes, o que foi considerado positivo para não se fugir do foco, mas que poderia ser colocada numa outra reunião específica sobre esse assunto:

“...fiquei impressionada com uma notícia sobre uma lei que obriga as mulheres a registrar sua gravidez no Peru. Isso inibiria o número de abortos, que é alto. Um absurdo, desrespeito aos direitos das mulheres".

\section{Segunda reunião}

Na segunda reunião houve bastante discussão, muitas sugestões foram apresentadas, sendo o resultado bastante rico em informações.

O pesquisador Daniel colocou a informação de as "procuras" serem um tanto cansativas na internet e que se perde muito tempo selecionando as informações ("fazendo uma "peneira"). Ele completa à frente que isto é decorrente de "procuras" não sistematizadas e, em seguida, sugere que haja um "espaço para orientação sobre procura". Normalmente os sites apresentam um setor de ajuda, inclusive a BVSR tem este espaço. O que pode ocorrer, às vezes, é que as pessoas não querem perder tempo lendo os itens de ajuda e vão diretamente para a pesquisa. Novamente transpareceu a necessidade de capacitação dos usuários.

Outra pesquisadora, Ester, colocou uma sugestão para portais, que seria "socializar informações sobre recursos disponíveis na internet para um público heterogêneo" para ajudar na triagem da informação, dificuldade levantada pelo Daniel. O moderador coloca, então, que a BVSR, como outros portais, embora busque o perfil do seu usuário, fica disponível também, para o 
público heterogêneo da internet. Se o site é aberto fica impossível controlar o seu uso.

A pesquisadora Paula também completou este raciocínio, sugerindo que a BVSR seja acessível aos alunos do ensino fundamental e médio, aos pesquisadores da área, às mulheres e homens interessados em informações sobre doenças sexualmente transmissíveis ou gravidez, aos secretários de saúde de municípios pequenos etc. $\mathrm{O}$ moderador fez uma observação de que provavelmente a BVSR tem muitos usuários adolescentes e Paula completou que trabalha com este público e o que eles procuram são informações em que não há contato pessoal, "que gera constrangimentos". Ela acredita que a internet seja uma fonte importante para os adolescentes, quando há possibilidade de acesso.

Ester retomou o assunto sugerindo que a BVSR trabalhe com segmentos de usuários, colocando o exemplo "público leigo e escolares, divulgando os sites 'teens' do IBGE e do MS; portal de periódicos da Capes e Pubmed para pesquisadores de ONGs e universidades - estes poderosos instrumentos encontram-se ainda subutilizados e pouco conhecidos". Paula também citou o exemplo do site do IBGE para teens, que motivou um comentário sobre a sintonia entre as duas participantes.

A sugestão de separar a BV para os segmentos de público, como estudantes, pesquisadores etc, parece ser interessante. Um exemplo disso já ocorre no site da National Library of Medicine - NLM - (www.nlm.nih.gov), que está segmentado para as categorias: público, profissionais de cuidados da saúde, pesquisadores, bibliotecários e editores. Dessa forma, o usuário entra na parte do site que traz as informações mais pertinentes às suas necessidades e numa linguagem mais adequada ao seu perfil. Segundo informações fornecidas por email, o website da NLM foi organizado nestes segmentos, a partir dos resultados de testes de uso de desenhos da nova página principal, feitos com os usuários. 
A pesquisadora Júlia comentou sobre a confiabilidade de sites e disse perceber que alunos de pós e vários docentes desconhecem as fontes mais seguras para busca da informação científica e acha que "talvez falte uma maior divulgação dessas fontes confiáveis". Continuando, ela comentou sobre o perfil do usuário de uma biblioteca virtual, sugerindo que uma mesma informação tenha seu conteúdo transformado para atendimento de cada segmento de usuário.

Houve um questionamento do Daniel para o moderador sobre como a BVSR lida com a demanda de informações do público adolescente sobre questões reprodutivas. A resposta foi que a BVSR conta com um professor na equipe para indicar sites ou profissionais a este público.

Verifica-se que as novas gerações, atuais adolescentes, utilizam a internet para a comunicação interativa com seus pares. Na sala de bate-papo foi comentado que este instrumento "é um excelente meio de comunicação, os adolescentes que o digam, 'pendurados' que ficam por horas no MSN'. Pode ser que esta geração esteja mais preparada para usar estes instrumentos mais tarde, no desenvolvimento de pesquisas e discussões temáticas, lembrando que isto só será possível se ocorrer a educação em seu sentido amplo. Alguns estudos psicológicos e sociológicos estão sendo feitos para avaliar as mudanças causadas por estas novas tecnologias no desenvolvimento cognitivo dos jovens. Alguns resultados apontam que estes jovens, assíduos usuários do computador para se comunicar entre si, parecem estar desenvolvendo estruturas de consciência fragmentadas e transitórias, ocasionando dificuldades de adaptação ao mundo social. Ao mesmo tempo, outros resultados consideram que essa nova consciência será mais flexível, adaptativa e positiva (RIFKIN 2001).

Outra posição é colocada por SCHWARTZ (2000) ao afirmar, baseado em três idéias que os adolescentes interagem com as novas tecnologias de comunicação com naturalidade e que a tendência é de ampliação: 1) as novas 
tecnologias estão se tornando baratas e poderosas; 2) o "adolescente global" irá “desejar" comunicar-se desta forma; 3) usar esse tipo de mídia tende a alterar o comportamento e os valores da pessoa, sendo que os valores passarão a ser as competências que este adolescente possui para transmitir para o outro, encorajando a inteligência ativa. Se as informações não forem compartilhadas entre as pessoas, elas perdem sua função e alcance social.

DELGADO-GÓMEZ (2002) trata do aumento do uso das bibliotecas virtuais pelos adolescentes, colocando que, no futuro, este hábito se tornará mais comum.

O adolescente, portanto, é um público mais aberto às comunicações no ciberespaço, devendo ser levado em consideração como um segmento de usuário da BVSR.

Quando foi tocado no assunto dos boletins eletrônicos o moderador perguntou se achavam que eles ajudavam na divulgação ou aborreciam as pessoas que recebem o mesmo pelo email. Como resposta a este questionamento foi sugerido que eles continuem trimestrais e tenham um “layout agradável" para não saturar o usuário com tanta informação e até aborrecê-lo. Paula acha válido o boletim para "lembrar da existência da página" e Ester diz que não dá conta de ler todos os que recebe.

Nesta reunião houve a interação entre os participantes, o que foi confirmado pelos exemplos de falas, a seguir:

"Tenho utilizado a internet cada vez mais (com os mesmos objetivos apontados por Ester)"

"Alguma forma de ajudar na triagem que o Daniel mencionou" "Concordo com Paula"

"Verdade, Ester. Gostei da sua sugestão da lista dos links confiáveis” 
"Concordo com Daniel que telefone é mais eficiente"

\section{Terceira reunião}

A terceira reunião teve um resultado menos expressivo em volume de informações, talvez pelo menor número de participantes e pela dificuldade de um dos pesquisadores ler as falas dos demais.

Nesta reunião foi comentado sobre a experiência positiva da Plataforma Lattes $^{*}$ do $\mathrm{CNPq}$, no que tange à divulgação dos pesquisadores brasileiros através da disponibilização dos seus currículos na internet. A participante Graça sugeriu que os usuários pesquisadores deveriam passar informações de pesquisas em andamento para a BVSR, como fazem no Currículo Lattes. A participante Cristina achou isto inviável, por falta de tempo e hábito dos pesquisadores. A discussão continuou com sugestões para que os pesquisadores recebessem periodicamente um email perguntando se têm novas pesquisas para divulgar na BVSR.

Existe um serviço no site da BVSR, atualmente em reestruturação, na categoria "Especialistas e Pesquisadores", onde é possível verificar uma lista de especialistas da área da saúde reprodutiva, com endereços para contato e curriculum vitae (quando possível é inserido o link para o Currículo Lattes). Uma complementação desta sugestão é integrar esta categoria do site aos trabalhos destes especialistas.

A sugestão de solicitação de publicações aos pesquisadores só será viável se a BVSR mudar o seu formato, incluindo também o armazenamento de documentos em seu servidor de rede, pois atualmente só há espaço para

\footnotetext{
* A Plataforma Lattes é uma experiência do CNPq de interação dos seus sistemas de informações gerenciais, articulados com outras bases de dados, das áreas de pesquisa no Brasil. Integra: Sistema Eletrônico de Currículos, Diretório dos Grupos de Pesquisa no Brasil, Diretório de Instituições, Sistema Gerencial de Fomento, base SciELO e Lilacs, base de Patentes do INPI e os bancos de dissertações e teses das universidades.
} 
links aos trabalhos. Como a BVSR passa por uma reformulação, esta sugestão também será enviada para estudo.

Em suma, foi sugerido que os pesquisadores participassem ativamente da BVSR, indicando sites e pesquisas para serem inseridos e comunicassem a obsolescência e a indisponibilidade de sites já registrados, para serem retirados.

Algumas frases mostraram a interação dos participantes:

"Concordo com os demais"

"Oi Raquel, acho que demora mesmo para rolar"

"Também acho Graça, mas concordo que..."

"Acho interessante esta resposta da Graça"

"A idéia da Graça é boa, serve como lembrete para enviar contribuições”

"Concordo com Raquel, o nosso problema foi a tecnologia não ir tão rápido quanto o nosso pensamento e vontade de falar ”

\section{CONCLUSÕES E RECOMENDAÇÕES}

Com base nos resultados dos grupos focais pode-se concluir que os usuários da BVSR não conhecem todos os serviços por ela oferecidos, bem como seus objetivos e estrutura. Os serviços são subutilizados e a falta de divulgação é a maior barreira nesta comunicação.

Outra barreira na comunicação BVSR x usuário é que este último nem sempre está disponível para interagir. A cultura da comunicação interativa está no início, mas a BVSR deve oferecer e provocar esta interação, assumindo o papel de promover a inteligência coletiva. 
As sugestões apresentadas para a comunicação interativa, levantadas pelos sujeitos da pesquisa, potenciais usuários, vão contribuir para a reformulação desta biblioteca virtual, já em fase de avaliação para mudança, bem como para outras bibliotecas virtuais já existentes ou em vias de criação. Destacam-se:

- As bibliotecas virtuais devem se constituir em espaço de encontro de pessoas e instituições, seja em salas de batepapo, fóruns etc. Esta é uma demanda que tende a aumentar.

- Deve ser estudada a possibilidade de segmentação das bibliotecas virtuais para diferentes públicos: pesquisadores, adolescentes, funcionários da saúde, gestores etc. A BVSR foi instituída para atender aos pesquisadores da área da saúde reprodutiva, porém é necessário verificar o perfil do usuário e fazer as adequações necessárias.

- Estudar um novo programa que possibilite a integração de bases de dados, textos completos, bibliografias e sites dentro da sua estrutura.

- Continuar a divulgação de diferentes tipos de material: artigos de periódicos, teses, cópias de notícias da mídia, pesquisa bibliográfica, imagens, dados estatísticos com tabelas e gráficos, bases de dados e catálogos de bibliotecas. As fontes devem ser validadas e confiáveis.

- Possibilitar a disponibilização de contato com outros pesquisadores, autores dos trabalhos divulgados na BVSR

- Propiciar a solicitação periódica aos pesquisadores de contribuições com pesquisas recentes.

- Apresentar um visual mais moderno e provocativo do site, com páginas ágeis e dinâmicas, sem poluição e sem perder de 
vista a página principal. Estudar a necessidade do site ser organizado em grandes blocos de assunto, com destaque para o espaço destinado à comunicação com a equipe.

- Propiciar edição de boletins eletrônicos, com visual agradável e seu envio para os usuários cadastrados.

- Proceder ao atendimento virtual com respostas rápidas, atenciosas e qualificadas às solicitações por email, telefone, carta etc.

- Atentar à atualização constante dos links das páginas.

- Possibilitar aos usuários a sugestão de novos assuntos de interesse, além dos sites.

- Promover a divulgação da BVSR nas Organizações Governamentais, não Governamentais e outras instituições da área de saúde reprodutiva.

Recomendações:

- É necessário promover, periodicamente, estudos com usuários para conhecer qual a sua demanda e perfil. É provável que o usuário da BVSR tenha vários perfis e a sugestão da segmentação para os diversos públicos deve ser levada em conta na sua reestruturação, incluindo o público adolescente, futuros pesquisadores.

- Promover a comunicação "todos-todos”, pois é através desse meio que se obtêm idéias, capacitam-se os usuários e divulga-se a BVSR. A ferramenta empregada no presente trabalho, grupo focal via internet, foi bastante positiva e pode servir de exemplo para as equipes das bibliotecas virtuais se comunicarem com seus usuários. Sugere-se o uso dos 
emoticons para permitir a transmissão dos sentimentos também, bem como outros recursos que venham a ser oferecidos.

- Para implementação destas sugestões é necessário o trabalho de uma equipe capacitada, que congregue profissionais da informação e especialistas na área temática. Cabe reforçar que o profissional da informação deve procurar especializarse na área temática em que trabalha para tornar mais fácil a promoção de grupos de discussão, oferecer informações com qualidade e perceber as necessidades dos usuários da informação. 


\section{REFERÊNCIAS}

Abracinskas L. Nenhum passo atrás, todos para frente! J Redesaúde 1999; (18):2-4.

Alvarenga AT de, Schor N. Contracepção feminina e política pública no Brasil: pontos e contrapontos da proposta oficial. Saúde Soc 1998; 7(1):87110.

Arellano MAM. Serviço de referência virtual. Ciênc Inform 2001; 30(2):113.

Barreto A de A. A questão da informação. São Paulo Perspect 1994; 8(4):38.

Barreto A de A. A eficiência e a viabilidade de produtos e serviços de informação. Ciênc Inform 1996; 25(3): 1-18.

Barreto A de A Cambio estrutural em el flujo del conocimiento: la comunicación electrónica. ACIMED 2001; 9supl:23-7.

Bilac ED, Rocha MIB da. Saúde reprodutiva na América Latina e no Caribe: temas e problemas. Campinas: PROLAP/ABEP/NEPO/UNICAMP/ São Paulo: ED 34; 1998. Introdução; p.9-20.

[BIREME/OPS] Centro Latinoamericano y del Caribe de Información em Ciências de la Salud. Biblioteca Virtual de Salud. São Paulo; 1998.

Buckland M. Information as thing. J Am Soc Inform Sci 1991; 42(5):351-60.

Carlini-Cotrim B. Potencialidades da técnica qualitativa grupo focal em investigações sobre abuso de substâncias. Rev Saúde Pública 1996; 30(3):285-93.

Castells M. A sociedade em rede. São Paulo: Paz e Terra; 1999. (A Era da Informação: economia, sociedade e cultura, v.1).

Castro NJ, Magalhães MAE de, Lima MS de. Análise do perfil dos usuários cadastrados nos serviços do Prossiga: junho de 2001. Rio de Janeiro: Programa PROSSIGA CNPq/MCT; 2001.

Chase L, Alvarez J. Internet research: the role of the focus group. Library Inform Sci Res 2000; 22(4):357-69.

Chastinet YS. Histórico das bibliotecas virtuais do PROSSIGA [online]. Rio de Janeiro: MCT/CNPq/PROSSIGA; 1999. Disponível em 
URL:http://www4.prossiga.br/marketing/doctec/doc99-02v.1.html [2002 set 23]

Chauí M. Convite à filosofia. $12^{\mathrm{a}}$. ed. São Paulo: Ática; 2001. O universo das artes; p.314-33.

Cianconi A. A gestão da informação na sociedade do conhecimento. $2^{\mathrm{a}}$. ed. Brasília: SENAI/DN; 2001.

Ciência da Informação. Brasília 1997; 26(2).

Clapper DL, Massey AP. Electronic focus group: a framework for exploration. Inform Manag 1996; 30:43-50.

Coelho CNP. A comunicação virtual segundo Lévy e Baudrillard. In: $\mathbf{2 4}^{\mathbf{0}}$. Congresso Brasileiro de Ciências da Comunicação [online]; 2001; Campo Grande (MS). São Paulo: Intercom; 2001. Disponível em URL:http://intercom.org.br/papers/indexbp.html [2002 jun 15]

Correa S. Vozes da América Latina: mais amplas e consensualmente progressistas. J Redesaúde 1999; (18):6-7.

Crowley A. Looking for data in all right places (online focus group). PC Week 1996; 13(42):51-3.

Cuenca AMB. O uso da Internet por docentes da área de saúde pública no Brasil. São Paulo; 2004. [Tese de doutorado - Faculdade de Saúde Pública da USP]

Cuenca AMB, Alvarez M do CA, Ferraz MLE de F, Garbin VL. O usuário remoto de uma biblioteca acadêmica na área de saúde pública [online].

Inform Soc 2003; 13(2). Disponível em < http://www.informacaoesociedade.ufpb.br > [2004 abr 6]

Cunha MB da. Construindo o futuro: a biblioteca universitária em 2010. Ciênc Inform 2000; 29 (1):71-89.

Delbúcio H, França Junior I. Paternidade na adolescência: avaliação do desempenho de ferramentas de metabusca na recuperação de informações na Web. [Apresentado no $8^{\circ}$ Simpósio Internacional de Iniciação Científica da USP; 2000; Ribeirão Preto]

Delgado-Gómez AF. Young adults and virtual libraries: a case study. New Libr World 2002; 103(1178/1179):277-283. 
Denzin NK, Lincoln YS, editors. Handbook of qualitative research. $2^{\text {nd }}$ ed. Thousand Oaks: Sage; 2000. Introduction: the discipline and practice of qualitative research; p.1-28.

Dias EW. O específico da ciência da informação. In: Aquino M de A, organizador. $O$ campo da ciência da informação: gênese, conexões e especificidades. João Pessoa: Editora Universitária /UFPB; 2002. p. 87-99.

Eysenbach G, Köhler C. How do consumers search for and appraise health information on the world wide web: qualitative study using focus group, usability tests, and in-depth interviews. BMJ 2002; 324:573-7.

Fassler M. Moments of cyber-modernity: interacting in distributed artificial societes. In: Anais do Simpósio Internacional Universidade e Novas Tecnologias: impactos e implicações; 1998 abr 3-4; São Paulo (BR). São Paulo: Rede Macunaíma do Projeto Alfa; 1998. p.91-7.

Fontes $\mathrm{C}$ de $\mathrm{A}$. Usos e efeitos da Internet na prática bibliotecária: estudo exploratório junto aos Sistema Integrado de Bibliotecas da Universidade de São Paulo (SIBi/USP). São Paulo; 2001. [Dissertação de mestrado Escola de Comunicações e Artes da USP].

França Junior I, Abdalla ERF, Ferraz MLEF, Duque A, Andrade MTD, Siqueira AA. Biblioteca virtual de saúde reprodutiva(BVSR): caracterizando seus usuários [resumo] In: Livro de resumos do $2^{\mathbf{0}}$ Congresso Brasileiro Ciências Sociais em Saúde; 1999 dez 7-10; São Paulo(BR). Rio de Janeiro: ABRASCO; 1999a. p. 171.

França Junior I, Abdalla ERF, Ferraz MLEF, Duque A, Andrade MTD, Siqueira AA. Biblioteca virtual de saúde reprodutiva(BVSR): seus primeiros movimentos [resumo] In: Livro de resumos do $2^{\mathbf{0}}$ Congresso Brasileiro Ciências Sociais em Saúde; 1999 dez 7-10; São Paulo(BR). Rio de Janeiro: ABRASCO; 1999b. p. 171.

França Junior I, Abdalla ERF, Ferraz MLEF, Duque A, Delbúcio H, Andrade MTD, Siqueira AA. Comunidades virtuais e a saúde coletiva: a Biblioteca Virtual de Saúde Reprodutiva(BV) [resumo] In: Livro de resumos do $6^{\circ}$. Congresso Brasileiro de Saúde Coletiva; 2000 ago 28-set 1; Salvador(BR). Rio de Janeiro: ABRASCO; 2000. posters 3.

Fundação IBGE. Os primeiros resultados definitivos de amostra do Censo 2000. Vou te Contar: Revista do Censo [online] 2002b; (9):6-10. Disponível em: <URL:http://www.ibge.gov.br/censo/revista.shtm> [2004 dez 10]. 
Fundação IBGE. Relação dos principais produtos e serviços 2002 [online]. Rio de Janeiro; 2002a. Disponível em: URL:http://www.ibge.gov.br [2004 dez 10]

Furquim T de A. Fatores motivadores de uso de site web: um estudo de caso. Ciênc Inform 2004; 33(1):48-54.

Gaiser TJ. Conducting on-line focus group: a methodological discussion. Soc Sci Comput Rev 1997; 15(2):135-44.

Galvão L. Saúde sexual e reprodutiva, saúde da mulher e saúde materna: a evolução dos conceitos no mundo e no Brasil. In: Galvão L, Diaz J, organizadores. Saúde sexual e reprodutiva no Brasil: dilemas e desafios. São Paulo: Hucitec; 1999. p.165-79.

Gomes SLR, Chastinet YS. Bibliotecas virtuais: avanços e desafios para cientistas e profissionais de informação. J Bibliotecas 1997; 4(6):5.

Gomes SLR, Chastinet YS, Henning P, Pereira M de NF, Santos L. Bibliotecas virtuais na Internet: a experiência do PROSSIGA. Ciênc Inform [online] 1996; 25(3):1-10. Disponível em URL:http:www4.prossiga.br/marketing/DocTec/Doc96.html [2002 sep 23]

Hummelshoj M. Do we really serve our users? A model for evaluation and development of reference services on the Internet [on-line]. International Federation of Library Associations and Institutions. IFLANET. Disponível em <URL: http://www.ifla.org/VII/dg/dgrw/dgrw5.htm>. [2000 ago 29].

Iturri J. Ciberespaço e negociações de sentido: aspectos sociais da implementação de redes digitais de comunicação em instituições acadêmicas de saúde pública. Cad Saúde Pública 1998; 14 (4):803-10.

Janes J, Carter D, Memmott P. Digital reference services in academic libraries. Ref User Serv Q 1999; 39(2):145-50.

Kerslake E, Goulding A . Focus groups: their use in LIS research data collection. Educ Inform 1996; 14:225-32.

Kitzinger J. Qualitative research: introducing focus group. BMJ 1995; 311:299-302.

Krueger RA, Casey MA. Focus group: a practical guide for applied research. $3^{\text {rd }}$ ed. Thousand Oaks: Sage; 2000. 
Lancaster FW. Ameaça ou oportunidade? O futuro dos serviços da biblioteca à luz das inovações tecnológicas. Rev Esc Biblioteconom UFMG 1994; 23(1):7-27.

Leitão BJM. Grupos de foco: o uso da metodologia qualitativa como suporte complementar à avaliação quantitativa realizada pelo Sistema de Bibliotecas da USP. São Paulo; 2003. [Dissertação de mestrado - Escola de Comunicações e Artes da USP].

Levacov M. Bibliotecas virtuais: (r)evolução? Ciênc Inform 1997; 26(2):12535.

Lévy P. As tecnologias da inteligência: o futuro do pensamento na era da informática. São Paulo: Editora 34; 1993.

Lévy P. O que é o virtual. São Paulo: Editora 34; 1996.

Lévy P. Cibercultura. São Paulo: Editora 34; 1999.

Lévy P. A inteligência coletiva. $3^{\text {a }}$ ed. São Paulo: Loyola; 2000.

Lévy P. A inteligência coletiva: nova fonte de potência [online]. In:

Conferencia Internet e Desenvolvimento Humano: as inteligências coletivas; 2002 ago 29; São Paulo (BR). São Paulo: SESC; 2002. Disponível em: URL:http://sescsp.org.br [2002 set 23]

Lopes IL. Novos paradigmas para avaliação da qualidade da informação em saúde recuperada na Web. Ciênc Inform 2004; 33(1):81-90.

Macedo ND de, Modesto F. Equivalências: do serviço de referência convencional a novos ambientes de redes digitais em bibliotecas. Rev Bras Bibliotecon Doc, Nova Série 1999; 1(1):55-72.

Maxey-Harris C. Chat reference service pilot. Net Libr Assoc Q 2003; 34(2):6-8.

Medeiros JWM. Entre a sociedade da informação e a inteligência coletiva: educação e (in)formação para a ação emancipatória [online]. Inform Soc: Estud 2001;11(2):1-15. Disponível em:

URL:http://www.informaçãoesociedade.ufpb.br [2001 jun 06]

Ministério da Ciência e Tecnologia. Livro branco: ciência, tecnologia e inovação. Brasília; 2002. [Disponível em http://

www.cgee.org.br/arquivos/livro_branco_cti.pdf] [2003 fev 10] 
Ministério da Saúde. Conselho Nacional de Saúde. Resolução 196, de 10 de outubro de 1996[online] Disponível

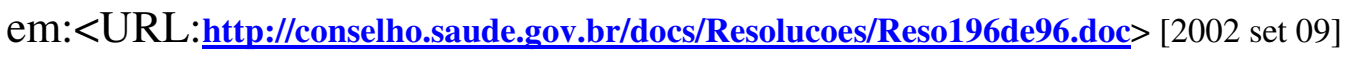

Monteiro SD. Aspectos filosóficos do virtual e as obras simbólicas no ciberespaço. Ciênc Inform 2004; 33(1):108-16.

Montoya-Weiss MM, Massey AP, Clapper DL. On-line focus groups: conceptual issues and a research tool. Eur J Mark 1998; 32(7/8):713-23.

Munro K, Zeidman-Karpinski A. A hitchhiker's guide to chat. OLA Q 2003; $9(2): 2-6$.

Network em Espanõl. Durham, NC, 2002; 27(2).

Neves VF. Perfil dos usuários da Biblioteca Virtual de Saúde Reprodutiva (BVSR) - FSP/USP - PROSSIGA/CNPq [resumo online]. São Paulo; 2001. [Trabalho apresentado na Semana de Iniciação Científica da Faculdade de Saúde Pública/USP; 2001] Disponível em: URL: 143.107.1.36/siicusp/cd_2001/ficha483.htm. [2002 jul 22]

O'Connor H, Madge C. Focus group in cyberspace: using the Internet for qualitative research. Qual Mark Res 2003; 6(2):133-43.

Ohira MLB, Prado NS. Bibliotecas virtuais e digitais: análise de artigos de periódicos brasileiros (1995/2000). Ciênc Inform 2002; 31(1):61-74.

Osis MJMD. Laqueadura e representações acerca da sexualidade e do papel reprodutivo. São Paulo; 2001. [Tese de Doutorado - Faculdade de Saúde Pública da USP].

Rifkin J. A era do acesso. São Paulo: Makron Books; 2001. Entrando na era do acesso, p. 3-12; Transformando as relações humanas em commodities; p.79-92.

Rodrigues AD. Comunicação e cultura: a experiência cultural na era da informação. Lisboa: Presença; 1994. p.13-39, p.128-134.

Samuelson RJ. O "abismo digital" cada vez se fecha mais. O Estado de São Paulo, São Paulo, 24 mar 2002. p.b6.

Schwartz P. A arte da visão de longo prazo: planejando o futuro em um mundo de incertezas. São Paulo: Best Seller; 2000. Anatomia de uma força motriz: o adolescente global; p. 105-16.

Sfez L. Informação, saber e comunicação. Informare 1996a; 2(1):5-13. 
Sfez L. A saúde perfeita: crítica de uma nova utopia. São Paulo: Universo/Loyola; 1996 b.

Shears KH. Múltiples usos de la investigación cualitativa. Netw Español 2002; 22(2):5-11.

Silva F M da. Internet - biblioteca - comunidade acadêmica: cnhecimentos, usos e impactos; pesquisa com três universidades paulistas (UNESP-UNICAMP-USP). São Paulo; 2001. [Tese de doutorado - Escola de Comunicações e Artes da USP].

Smit JW. Informação. In: Lima YD, Smit JW, organizadores. Organização de arquivos. São Paulo:IEB/ECA; 2002. p.19-31.

Smith M, Cadiz JJ, Burkhalter B. Conversation trees and Threaded Chats. In: Proceedings of the 2000 ACM Conference on Computers Supported Cooperative Work; 2000 Dec.; Philadelphia (US). New York: ACM Press; 2000. p. 97-105.

Takahashi T, organizador. Sociedade da informação no Brasil : livro verde. Brasília: Ministério da Ciência e Tecnologia; 2000.

Turato ER. Tratado de metodologia da pesquisa clínico-qualitativa.

Petrópolis: Vozes; 2003. Tratando e discutindo os dados para a contribuição do pesquisador ao repensar do conhecimento científico; p. 437-81.

Vogt C. Parábola do cão digital. Comciência [periódico online] 2002; (30). Disponível em URL: < http://www.comciencia.br/reportagens/internet/net01.htm> [2002 abr 04]

Wolpert A. Services to remote users: marketing the library' s role. Libr Trends 1998; 47(1):21-41. 


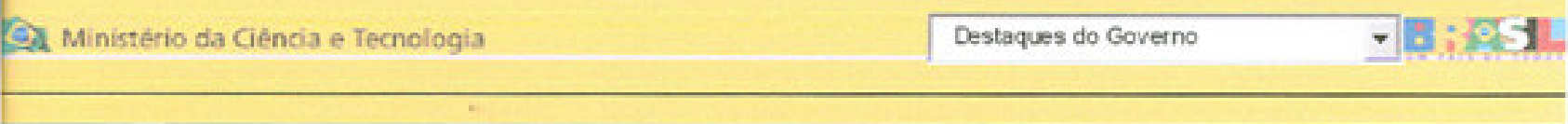

\section{Prossiga Notícias}

informaçăo e comunicaçào

para ciência e tecnologia

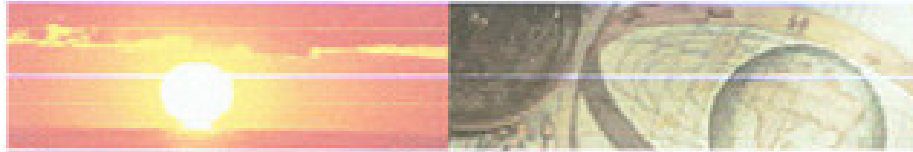

Prossiga em foco Informação

O que $\&$ o Prossiga

Contato

Livro de Visitas
Bases de Dados Brasileiras

Bibliotecas Virtuais Temáticas

Escritórios Virtuais

Eventos em CT\&! Novol

Instituiçōes de C\&T

Notaveis na C\&T do Brasil

Páginas Brasileiras

Pesquisas em C\&T no Brasil

Portal da Amazônia

Portal da Fome e Segurança

Alimentar Novid

Portal de Arquitetura e Urbanismo

Portal de Informaça Clentifica o

Tecnologica

Portal de Recursos Hidricos

Portal de Recursos Minerais

Portal de Referéncia para C\&T

Mercado de Trabalho em C\&T

Vortal de Cadeia Produtiva

Vortais de Arranjos Produtivos

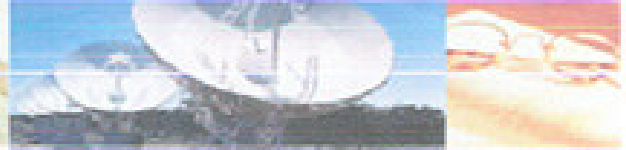

Comunicação

Educaç

Conexăo C\&T

Salas Virtuais - Chat

Escola Virti

Como acha

Internet 


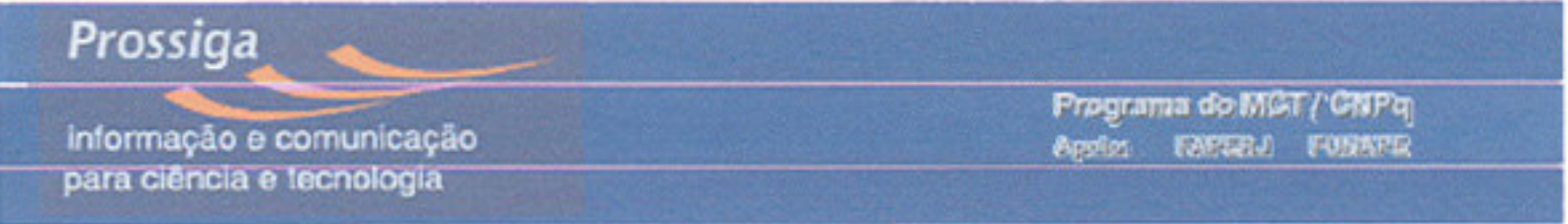

\section{Bibliotecas Virtuais Temáticas}

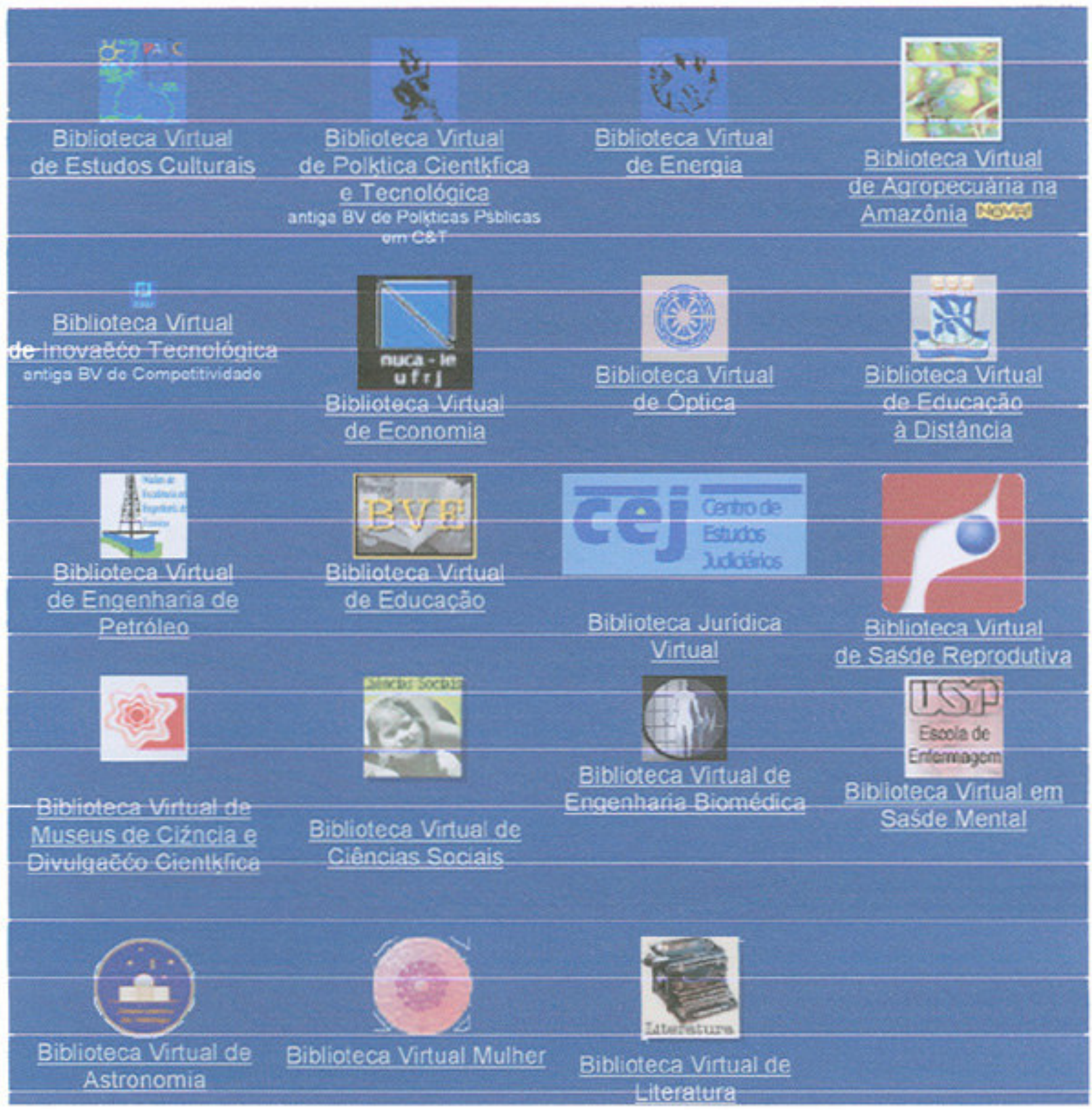




\section{Prossiga}

informaçăo e comunicação para ciência e tecnologia

\section{Biblioteca Virtual de Saúde Reprodutiva}

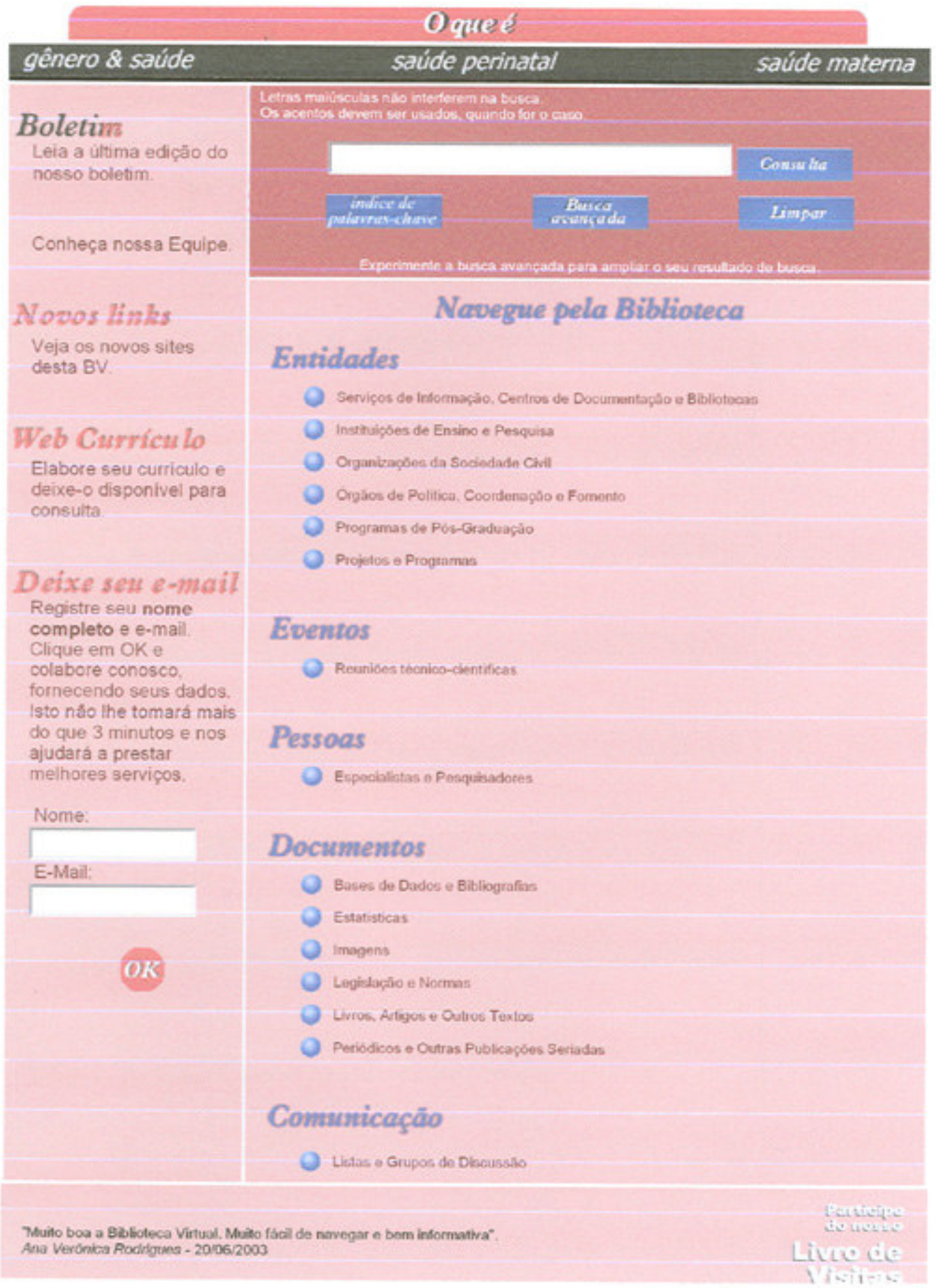


Anexo 4 - Instituiçoes contatadas da área de saude reprodutiva

\begin{tabular}{|c|c|}
\hline Instituiçes & $\begin{array}{l}\text { No de } \\
\text { pesquisadores } \\
\text { contatados }\end{array}$ \\
\hline Instituto PAPAI da Universidade Federal de Pernambuco & 3 \\
\hline $\begin{array}{l}\text { Centro de Pesquisa e Controle de Doenças Matemo-Infantis } \\
\text { (CEMICAMP) da UNICAMP }\end{array}$ & 2 \\
\hline Núcleo de Estudos de Glnero (PAGU) da UNICAMP & 2 \\
\hline Núcleo de Estudos da Populaçlo (NEPO) da UNICAMP & 2 \\
\hline $\begin{array}{l}\text { Depanamento de Medicina Preventiva da Universidade Federal } \\
\text { Paulista (UNIFESP) }\end{array}$ & 2 \\
\hline $\begin{array}{l}\text { Programa de Pós-graduaçio em Demografía (CEDEPLAR) da Un. Fed, } \\
\text { de Minas Gerais }\end{array}$ & 2 \\
\hline $\begin{array}{l}\text { Associaçlo Brasileira de Estudos Populacionais (ABEP) da Un. Fed. de } \\
\text { Minas Gerais }\end{array}$ & 2 \\
\hline $\begin{array}{l}\text { Grupo Antropologia do Corpo da Universidade Federal do Rio Grande } \\
\text { do Sul }\end{array}$ & 2 \\
\hline Instituto de Saúde do Estado de Sto Paulo & 1 \\
\hline Deparamento de Saude da Mulher da Universidade Federal da Paraiba & 2 \\
\hline Instituto de Saude Coletiva da Universidade Federal da Bahia & 4 \\
\hline
\end{tabular}




\begin{tabular}{|c|c|}
\hline Fundação Carlos Chagas & 4 \\
\hline $\begin{array}{l}\text { Núcleo de Estudos da Mulher e Género (NEMGE) da Faculdade de } \\
\text { Filosofia Letras e Ciências Humanas da USP }\end{array}$ & 6 \\
\hline $\begin{array}{l}\text { Departamento de Saúde Materno-Infantil da Faculdade de Saúde } \\
\text { Pública da USP }\end{array}$ & 4 \\
\hline $\begin{array}{l}\text { Núcleo de Estudos para Prevenção da AIDS do Instituto de Psicologia } \\
\text { da USP }\end{array}$ & 2 \\
\hline $\begin{array}{l}\text { Departamento de Enfermagem Materno-Infantil da Escola de } \\
\text { Enfermagem da USP }\end{array}$ & 4 \\
\hline $\begin{array}{l}\text { Departamento de Medicina Preventiva da Faculdade de Medicina da } \\
\text { USP }\end{array}$ & 2 \\
\hline Grupo de Trabalho de Género da ABRASCO & 2 \\
\hline $\begin{array}{l}\text { Departamento de Ciências Humanas e Saúde da Universidade Estadual } \\
\text { do Rio de Janeiro }\end{array}$ & 5 \\
\hline $\begin{array}{l}\text { Investigaç̧es Sociais em Gênero e Saúde da Escola Nacional de Saúde } \\
\text { Pública da FlocruZ }\end{array}$ & 5 \\
\hline
\end{tabular}

